\title{
A Review on the Reactivity of 1-Amino-2-Nitroguanidine (ANQ)
}

\author{
Jinghua Wang ${ }^{1}$, Meng Cai ${ }^{1}$, Fengqi Zhao ${ }^{2}$ and Kangzhen $\mathrm{Xu}^{1, *}{ }^{1}$ \\ 1 School of Chemical Engineering, Northwest University, Xi'an 710069, China; \\ 201831731@stumail.nwu.edu.cn (J.W.); cm201820747@163.com (M.C.) \\ 2 Xi'an Modern Chemistry Research Institute, Xi'an 710065, China; zhaofqi@163.com \\ * Correspondence: xukz@nwu.edu.cn; Tel.: +86-29-88307755
}

Academic Editor: Svatopluk Zeman

Received: 27 August 2019; Accepted: 4 October 2019; Published: 8 October 2019

\begin{abstract}
Amino-2-nitroguanidine (ANQ) is a high-energy nitrogen-rich compound with good detonation properties and low sensitivities. ANQ has only a central carbon atom with three small groups around it, including an amino, a hydrazine and a nitroxyl group. Though the molecular structure of ANQ is very simple, its reactivity is surprisingly abundant. ANQ can undergo various reactions, including reduction reaction, acylation reaction, salification reaction, coordination reaction, aldimine condensation reaction, cyclization reaction and azide reaction. Many new energetic compounds were purposely obtained through these reactions. These reactions were systematically summarized in this review, and detonation properties of some energetic compounds were compared. In the field of energetic materials, ANQ and some derivatives exhibit good application prospects.
\end{abstract}

Keywords: 1-Amino-2-nitroguanidine (ANQ); energetic materials; derivatives; energetic properties

\section{Introduction}

1-Amino-2-nitroguanidine (ANQ, 1) was first synthesized by Phillips in 1928 [1] and has played an important role in the synthesis of valuable biologically active compounds, such as pesticides and medicines [2-16]. In recent years, Klapötke has done a lot of research on the application of ANQ in high-energy nitrogen-rich materials, which began to attract significant interest in the field of energetic materials $[17,18]$. The molecular structure of ANQ is very simple, containing only an amino, a hydrazino and a nitro group around the central carbon atom and its non-hydrogen atoms are almost on the same plane. Moreover, the bond angles of three main groups in the molecule are about $120^{\circ}$ with a relatively uniform distribution, indicating that the structure is comparatively regular and conforms to the structural requirements of the energetic materials. One kind of intramolecular and five kinds of intermolecular hydrogen bonds exist in ANQ, which extend it into a two-dimensional planar structure. Meanwhile, a stable spatial structure of ANQ is formed by electrostatic attraction and van der Waals force between layers, as seen in Figure 1. The crystals of ANQ are transparent yellow and crystallize in the monoclinic crystal system with the space group $P 2_{1} / c$ [19]. ANQ can dissolve in water to the extent of $0.34 \%$ (mass fraction) at $20{ }^{\circ} \mathrm{C}$ and $3.0 \%$ at $70{ }^{\circ} \mathrm{C}$, and is easily soluble in sodium hydroxide solution, but cannot be readily dissolved in common organic solvents [1]. The decomposition behavior of ANQ presents two intense exothermal processes, and peak temperatures at a heating rate of $5^{\circ} \mathrm{C} \mathrm{min}-1$ are 192.48 and $196.20^{\circ} \mathrm{C}$, respectively, as presented in Figure 1 [20]. Furthermore, the self-accelerating decomposition temperature $\left(T_{\mathrm{SADT}}\right)$ and thermal explosion critical temperature $\left(T_{\mathrm{b}}\right)$ for ANQ are 184.5 and $192.7^{\circ} \mathrm{C}$ [20]. ANQ has good features, such as high nitrogen content $(58.8 \%)$, big density $\left(1.767 \mathrm{~g} \mathrm{~cm}^{-3}\right)$, decent detonation velocity $\left(8.25 \mathrm{~km} \mathrm{~s}^{-1}\right)$ and detonation pressure $(30.7 \mathrm{GPa})[21,22]$, suggesting that $\mathrm{ANQ}$ is a potential high-energy material. 


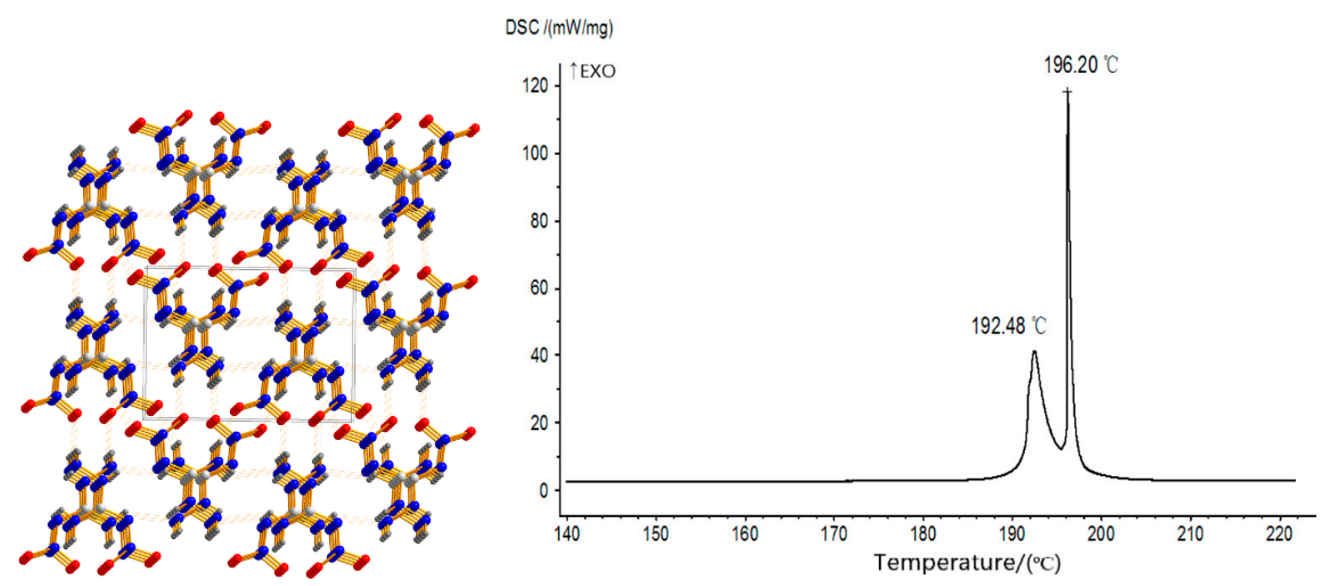

Figure 1. Packing diagram and DSC curve of 1-Amino-2-nitroguanidine.

The detonation performances of ANQ and other common energetic materials for comparison are shown in Table 1, including nitroguanidine (NQ, 2), 1,3,5-trinitroperhydro-1,3,5-triazine (RDX, 3), 2,4,6-trinitrotoluene (TNT, 4), and 1,1-diamino-2,2-dinitroethylene (FOX-7, 5) (Figure 2) [18,21-34]. $\mathrm{ANQ}$, as a suitable replacement for the high-energy explosive RDX, has similar detonation performances to NQ, RDX and FOX-7 and superior detonation performance to TNT.

Table 1. General and detonation performance comparison of ANQ, NQ, RDX, TNT, and FOX-7.

\begin{tabular}{cccccc}
\hline & ANQ & NQ & RDX & TNT & FOX-7 \\
\hline$M^{\mathrm{a}}\left(\mathrm{g} \mathrm{mol}^{-1}\right)$ & 119.08 & 104.07 & 222.12 & 227.13 & 148.08 \\
$\rho^{\mathrm{b}}\left(\mathrm{g} \mathrm{cm}^{-3}\right)$ & 1.767 & 1.759 & 1.80 & 1.663 & 1.885 \\
$\Delta_{\mathrm{f}} H^{\mathrm{c}}\left(\mathrm{kJ} \mathrm{mol}^{-1}\right)$ & 161.7 & -86 & 70 & -59.4 & -32.0 \\
$T_{\mathrm{dec}}{ }^{\circ}\left({ }^{\circ} \mathrm{C}\right)$ & 184 & 254 & 205 & 295 & 237.2 \\
$P^{\mathrm{e}}(\mathrm{GPa})$ & 30.7 & 29.0 & 34.9 & 19.1 & 28.4 \\
$V_{\mathrm{det}^{\mathrm{f}}\left(\mathrm{m} \mathrm{s}^{-1}\right)}$ & 8250 & 8344 & 8795 & 6928 & 8325 \\
$\mathrm{IS}^{\mathrm{g}}(\mathrm{J})$ & 20 & $>50$ & 7.5 & $39.4^{\mathrm{n}}$ & 24.7 \\
$\mathrm{FS}^{\mathrm{h}}(\mathrm{N})$ & 144 & $>355$ & 120 & $>353^{\circ}$ & $>350$ \\
$\mathrm{ESD}^{\mathrm{i}}(\mathrm{J})$ & 0.15 & - & 0.2 & 0.25 & 0.45 \\
$\mathrm{~N}^{\mathrm{j}}(\%)$ & 58.8 & 53.83 & 37.84 & 18.5 & 43.24 \\
OB $^{\mathrm{k}}(\%)$ & -33.59 & -30.75 & -21.6 & -74.0 & -21.61 \\
Reference $^{\mathrm{m}}$ & {$[18]^{1},[21,22]$} & {$[23]^{\mathrm{m}}$} & {$[24],[25]^{1},[26]$} & {$[26-29]$} & {$[30-34]$} \\
\hline
\end{tabular}

${ }^{a}$ Molecular mass. ${ }^{b}$ Crystal density. ${ }^{c}$ Molar enthalpy of the formation of compound. ${ }^{\mathrm{d}}$ Decomposition temperature. e Detonation pressure. ${ }^{\mathrm{f}}$ Detonation velocity. ${ }^{\mathrm{g}}$ Impact sensitivity. ${ }^{\mathrm{h}}$ Friction sensitivity. ${ }^{\mathrm{i}}$ Sensitivity to the electrostatic discharge. ${ }^{j}$ Nitrogen content. ${ }^{\mathrm{k}}$ Oxygen balance. ${ }^{1}$ IS: STANAG 4489 modified instructions, BAM Drop Hammer; FS: STANAG 4487 modified instructions, BAM friction tester; ESD: OZM, the Electric Spark Tester ESD 2010 EN. ${ }^{\mathrm{m}}$ IS: the BAM test (UN Test Series 3(a)(ii), with the $30 \mathrm{~kg}$ Fall Hammer-test (UN Test series 3(a)(iv). ${ }^{\mathrm{n}}$ IS: $\mathrm{h}_{50}$ of $160 \mathrm{~cm}, 2.5 \mathrm{~kg}$ Hammer. ${ }^{\circ} \mathrm{FS}$ : BAM friction tester.<smiles>NNC(N)=[N+](N)[O-]</smiles><smiles>NC(N)=[N+]([O-])O</smiles>

2<smiles>O=[N+]([O-])N1CN([N+](=O)[O-])CN([N+](=O)[O-])C1</smiles>

3<smiles>O=[N+]([O-])c1cc([N+](=O)[O-])c([N+](=O)[O-])c([N+](=O)[O-])c1</smiles>

4<smiles>NC(N)=C([N+](=O)[O-])[N+](=O)[O-]</smiles>

5

Figure 2. Structures of ANQ, NQ, RDX, TNT, and FOX-7.

To the synthesis of ANQ, Phillips first reported ANQ with the yield of 50\% through the reaction of hydrazine sulfate and nitroguanidine (6) in aqueous ammonia at 50-60 ${ }^{\circ} \mathrm{C}$ [1]. Castillo-Meléndez improved the method by dissolving nitroguanidine and $80 \%$ hydrazine hydrate in water at $55{ }^{\circ} \mathrm{C}$ for 15 min with the yield of $60 \%$, but the reaction temperature and reaction time must be precisely 
controlled [35]. Two side-products, including aminoguanidine (7) and diaminoguanidine (8), would be found in the reaction [18]. Assuming an addition-elimination mechanism, a probable reason is that there are two competitive reactions in the deamination condensation process of intermediate 9, which containing a tetrasubstituted carbon atom is formed by the reaction of nitroguanidine and hydrazine hydrate. One is that the intermediate 9 loses ammonia to form ANQ; the other is that the intermediate 9 loses nitramine to form aminoguanidine (7). In addition, using a larger excess of hydrazine hydrate, the resulting ANQ can continue to react with hydrazine hydrate forming intermediate 10, which eliminates nitramine to obtain 1,2-diaminoguanidine (8) [18,36]. Using a larger excess of nitroguanidine, ANQ continues to react with nitroguanidine to form intermediate 11, and hydrazobis (nitroformamidine) (12) is further obtained, as seen in Scheme 1 [37]. Another method was reported by Astrat'yev in 2002 [38]. In this report, ANQ was readily prepared using 1,2-dinitroguanidine (13) and 25\% hydrazine hydrate in aqueous at $70-80{ }^{\circ} \mathrm{C}$ for $2 \mathrm{~h}$ with the yield of $90 \%$ (Scheme 2), but compound 13 is more difficult to obtain, so the method is rarely used for the synthesis of ANQ. In 2016, Jia also reported a new synthesis method for ANQ based on the reaction of 2-methyl-3-nitroisothiourea (14) with hydrazine hydrate $(80 \%)$ at $40-70{ }^{\circ} \mathrm{C}$ (Scheme 3$)$, which possessed short synthesis steps and simple post-processes, but the yield was low, only $47 \%[39,40]$.
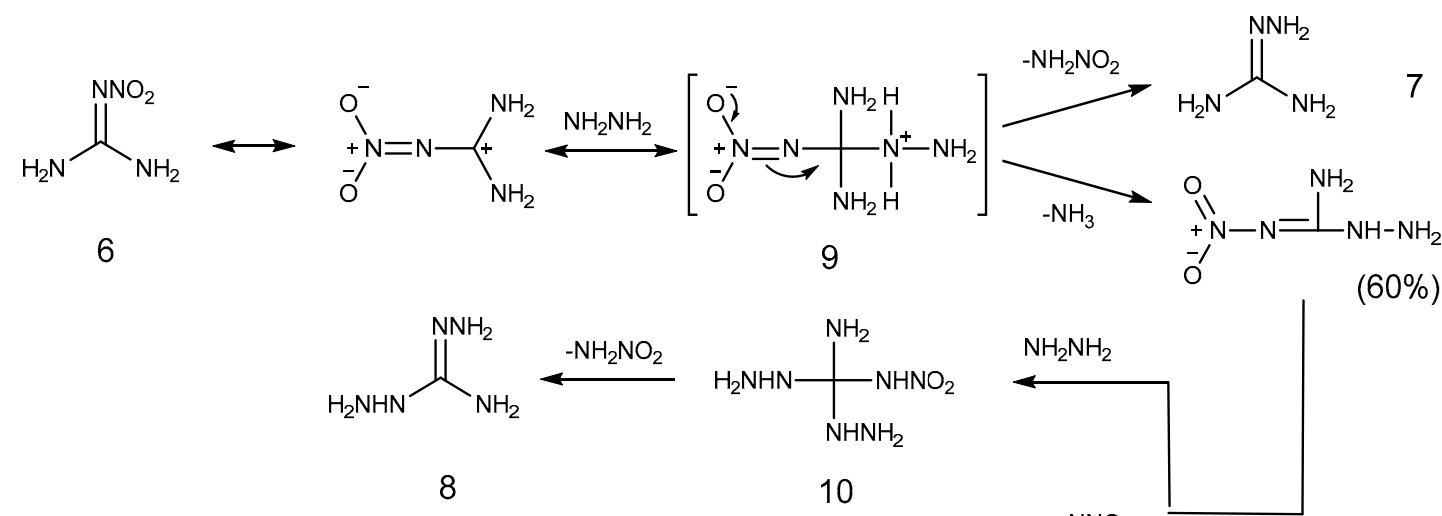

$(60 \%)$

8

10<smiles></smiles>

12

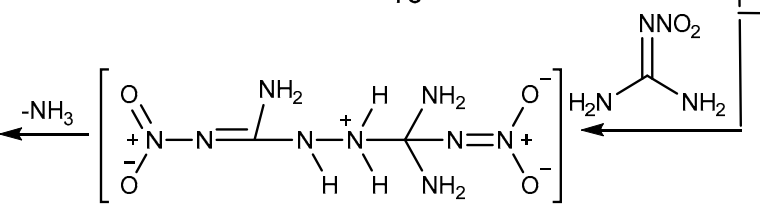

11

Scheme 1. Synthetic route of ANQ from nitroguanidine.

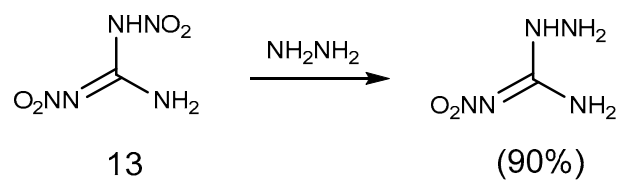

Scheme 2. Synthetic route of ANQ from 1,2-dinitroguanidine.

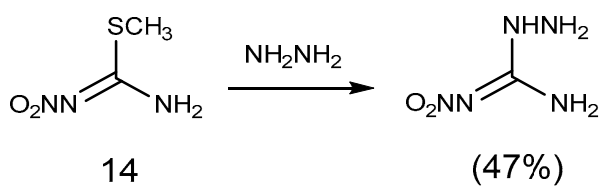

Scheme 3. Synthetic route of ANQ from 2-methylnitroisothiourea.

The molecular structure of ANQ can be regarded as a resonance hybrid between the mesomer 1 and 1-a, 1-b, 1-c, as seen in Scheme 4 [41]. It is noted that the structure is similar to that of NQ. We know that NQ has long been considered to exist in two isomers. However, in terms of reactivity and 
spectroscopic data, the structure of NQ is not a nitramine (B), but a nitrimine (A), as seen in Figure 3. This fact suggests that ANQ is a nitrimine structure as well [23]. Due to the misunderstanding of the structure of ANQ, it has long been considered as an amphoteric substance [19,42,43]. However, according to the nitrimine structure of ANQ, it is an alkaline substance and is easily protonated. Of course, owing to its electron-withdrawing nitro group and electron-donating hydrazino group, ANQ possesses a high reactivity, and the reactivity can be described as the following four aspects: (a) due to the protonation of the terminal amino group, ANQ can generate salification reaction; (b) due to the high electron density of amino and nitro groups, it can be used as a good ligand in many coordination reactions; (c) the nucleophilic substitution of the hydrazino group; (d) other reactions of the nitro group and the amino group.<smiles>CCCCCCCCCCC(N)=[N+]([O-])ON</smiles>

1<smiles>N=C(N=[N+]([O-])[O-])N[NH3+]</smiles>

1-a<smiles>NNC(=[NH2+])N=[N+]([O-])[O-]</smiles>

$1-b$<smiles>N[NH+]=C(N)N=[N+]([O-])[O-]</smiles>

1-c

Scheme 4. Resonance hybrid of ANQ.<smiles>NC(N)=[N+]([O-])O</smiles>

A<smiles>N=C(N)N[N+](=O)[O-]</smiles>

B

Figure 3. Correct nitrimine structure (A) and wrong nitramine structure (B) of nitroguanidine.

\section{Reactivity of ANQ}

\subsection{Reduction Reaction}

The reduction of ANQ by hydrogen can obtain diaminoguanidine (8) [1], as seen in Scheme 5, but no relevant papers confirmed the feasibility of the synthesis method. However, compound 8 can be obtained in the synthesis process of ANQ, as seen in Scheme 1, if the reaction temperature and time are not properly controlled [18].

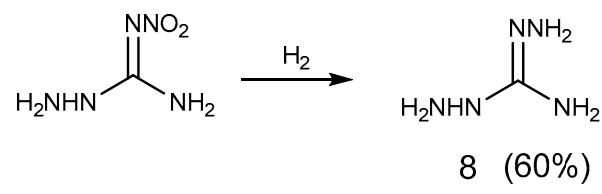

Scheme 5. Reduction reaction of ANQ.

\subsection{Acylation Reaction}

In the temperature range of 85 to $90{ }^{\circ} \mathrm{C}$, ANQ could be acylated by acetic anhydride-acetic acid to form 1-acetamido-2-nitroguanidine (15) with a very high yield (97.5\%) [44]. However, at room temperature, ANQ could react with acetic acid to form compound $\mathbf{1 5}$ which was easier to be hydrogenated than ANQ, and 1-acetamido-2-aminoguanidine (16) also could be obtained in the presence of zinc acetate. Theoretically, the cyclization reaction of compound 16 may occur at $\mathrm{N}^{1}, \mathrm{~N}^{2}$ or $\mathrm{N}^{3}$ and lead to the formation of the corresponding three products. However, the evidence suggested that this ring-closure reaction occurred mainly at $\mathrm{N}^{2}$, and 3-methyl-4,5-diamino-1, 2,4-triazole (17) was easily obtained, as seen in Scheme 6 [45]. Reaction with oxalic acid in aqueous solution at 92-94 ${ }^{\circ} \mathrm{C}$ for $8 \mathrm{~h}$ resulted in the corresponding mono- and di-hydrazides, compounds 18 and 19. Both of them were able to be cyclized to form nitroaminotriazole derivatives $(20,21)$ in the presence of alkaline material, as seen in Scheme 7 [46]. 5,5'-Bi(3-nitroamino-1,2,4-triazole) potassium salt (21) can also be 
obtained from 5(3)-nitroamino-1,2,4-triazole-3(5)-carboxylic acid (20) after a series of reactions, as seen in Scheme 8 [46].

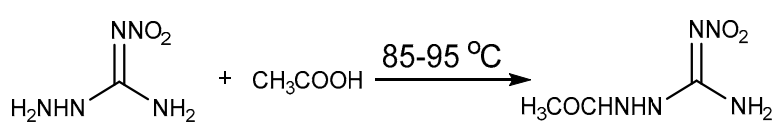

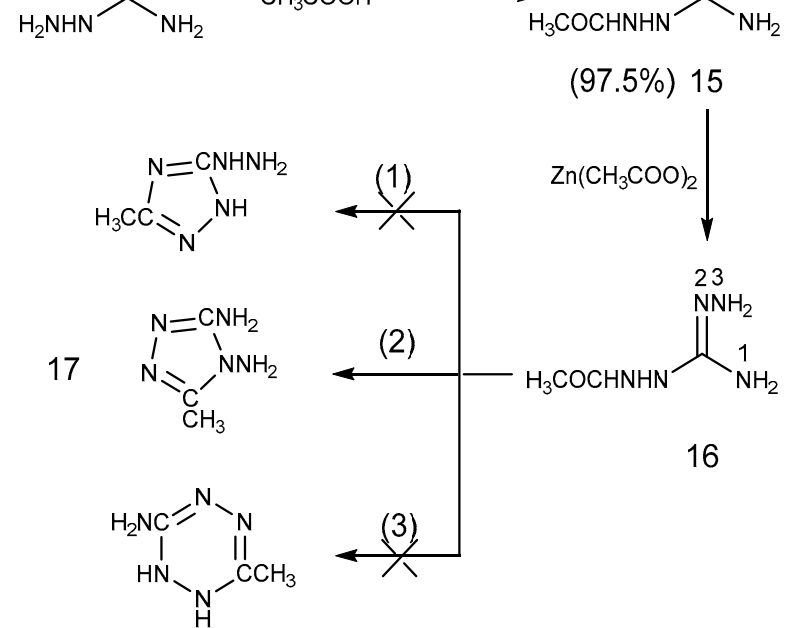

Scheme 6. Acylation of ANQ with acetic acid.<smiles></smiles><smiles>CC(C)CONc1n[nH]c(-c2n[nH]c(NNC(C)C)n2)n1</smiles>

$20(98 \%)$

$21(94 \%)$

Scheme 7. Acylation of ANQ with oxalic acid.

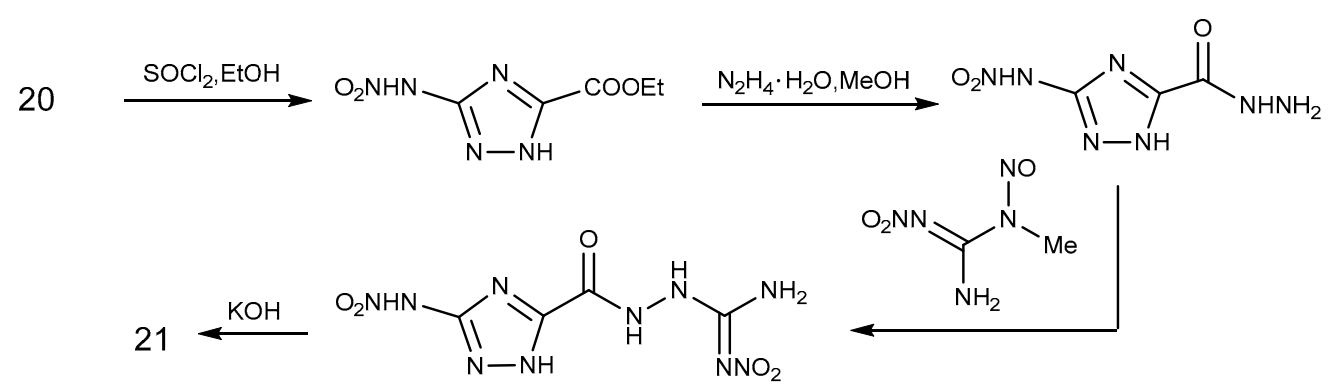

Scheme 8. Reaction of compound 21 from compound 20.

\subsection{Salification Reaction}

Since the hydrazine group is electron-donating, ANQ is easily protonated to form cations under strong acidic conditions, as seen in Scheme 9, which leads to the formation of the inorganic salts (22-27) and organic salts (28-42) of ANQ. For example, ANQ can react with nitric acid to form 1-amino-2-nitroguanidinium nitrate (ANGN, 22), which crystallizes in the triclinic crystal system with space group $P \overline{1}$ [47]. In addition, the halides as well as the sulfate salt also can be prepared by dissolving 
ANQ in dilute aqueous solutions of the respective mineral acids $\mathrm{HCl}, \mathrm{HBr}, \mathrm{HI}$ and $\mathrm{H}_{2} \mathrm{SO}_{4}$. However, it cannot react with $\mathrm{HF}$, since the acidic strength of $\mathrm{HF}$ in aqueous solution is the weakest among all the hydrogenides, and HF is not able to protonate ANQ in aqueous solution [48]. Especially, the detonation pressure (42.7 GPa) and detonation velocity $\left(9.551 \mathrm{~km} \mathrm{~s}^{-1}\right)$ of ANGN are both superior to those of RDX, which can be considered as a potential candidate for high-energy-density compounds [18].

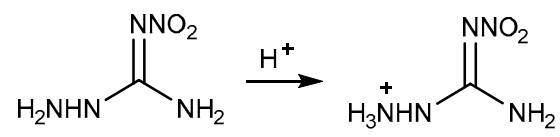

Scheme 9. ANQ and its protonated cation.

The hydrochloride salt of ANQ can react with organic silver salts to obtain some organic salts of ANQ, such as 2,4,5-trinitroimidazole salt (28), 5-nitro-1,2,3,4-tetrazole salt (29) [49], 4-nitroamino-1,2,4-triazole salt (30) [50], 3,5-dinitro-1,2,4-triazole salt (31) [51], 3-hydroxy-5-nitrotetrazole salt (32) [52] and dinitramide monohydrate salt (33) [18]. Those organic salts contain a large amount of $\mathrm{C}-\mathrm{N}$ and $\mathrm{N}-\mathrm{N}$ bonds, so the formation enthalpies and detonation characteristics of these materials are greatly improved. For the above compounds, except 33, thermal decomposition processes of these compounds present an evident sharp exothermic peak. The peak temperatures fall in the range $108-271.1^{\circ} \mathrm{C}$, and the heat releases are over the range of $1167-2589 \mathrm{~J} \mathrm{~g}^{-1}$. Compounds 29 and 32 have lower melting points as 83.2 and $93.8^{\circ} \mathrm{C}$, and compound 32 has the highest critical explosion temperature at $162.9^{\circ} \mathrm{C}$. The densities, standard molar formation enthalpies, detonation pressures and detonation velocities of these compounds (28-33) distribute in 1.59-1.85 $\mathrm{g} \mathrm{cm}^{-3}, 264.7-551.4 \mathrm{~kJ} \mathrm{~mol}^{-1}$, 26.6-37.7 GPa and 8.05-9.17 $\mathrm{km} \mathrm{s}^{-1}$, respectively [53].

ANQ reacted with dinitroguanidine to obtain corresponding dinitroguanidinium salt (34) [18]. Li found that 1-amino-2-nitroguanidinium 3,5-dinitrosalicylate (ANQ·DNS) (35) can be obtained by using 3,5-dinitrosalicylic acid in aqueous solution at $80{ }^{\circ} \mathrm{C}$ [19]. Analogously, the treatment of ANQ with azine compound cyanuric acid (CA) resulted in ANGDTO (36) $\left(\rho=1.75 \mathrm{~g} \mathrm{~cm}^{-3}\right)$ [54]. Moreover, ANQ can react with tetrazole to form corresponding 5-nitriminotetrazolium salt (37) [18], 5,5'-bis(tetrazole-2-oxide) salt (38) [55], 1-(2H-tetrazol-5-yl)-5-nitrosyltetrazolium salt (39) [56] and 5-nitroguanidyltetrazolium salt (40) [57]. Compound 39 shows an ultrahigh detonation velocity (9.432 $\mathrm{km} \mathrm{s}^{-1}$ ), indicating that it can be used as a high explosive. In addition, the reaction of ANQ with 3,3'-bis(1,2,4-oxadiazolyl)-5,5'-bis(2,2'-dinitro)-diacetic acid diethyl ester formed aminonitroguanidinium nitrogen-rich salts $\left(\mathrm{HANG}_{2}-\mathrm{DBO}, 41\right)$ in aqueous methanol solution [58]. Energetic salt 42 can be synthesized from the reaction of 5-nitramino-3,4-dinitropyrazole with ANQ. The result indicates that compound 42 exhibits good performances with high detonation pressure and detonation velocity as $39.5 \mathrm{GPa}$ and $9.237 \mathrm{~km} \mathrm{~s}^{-1}$ [59]. All reactions are gathered in Scheme 10. 


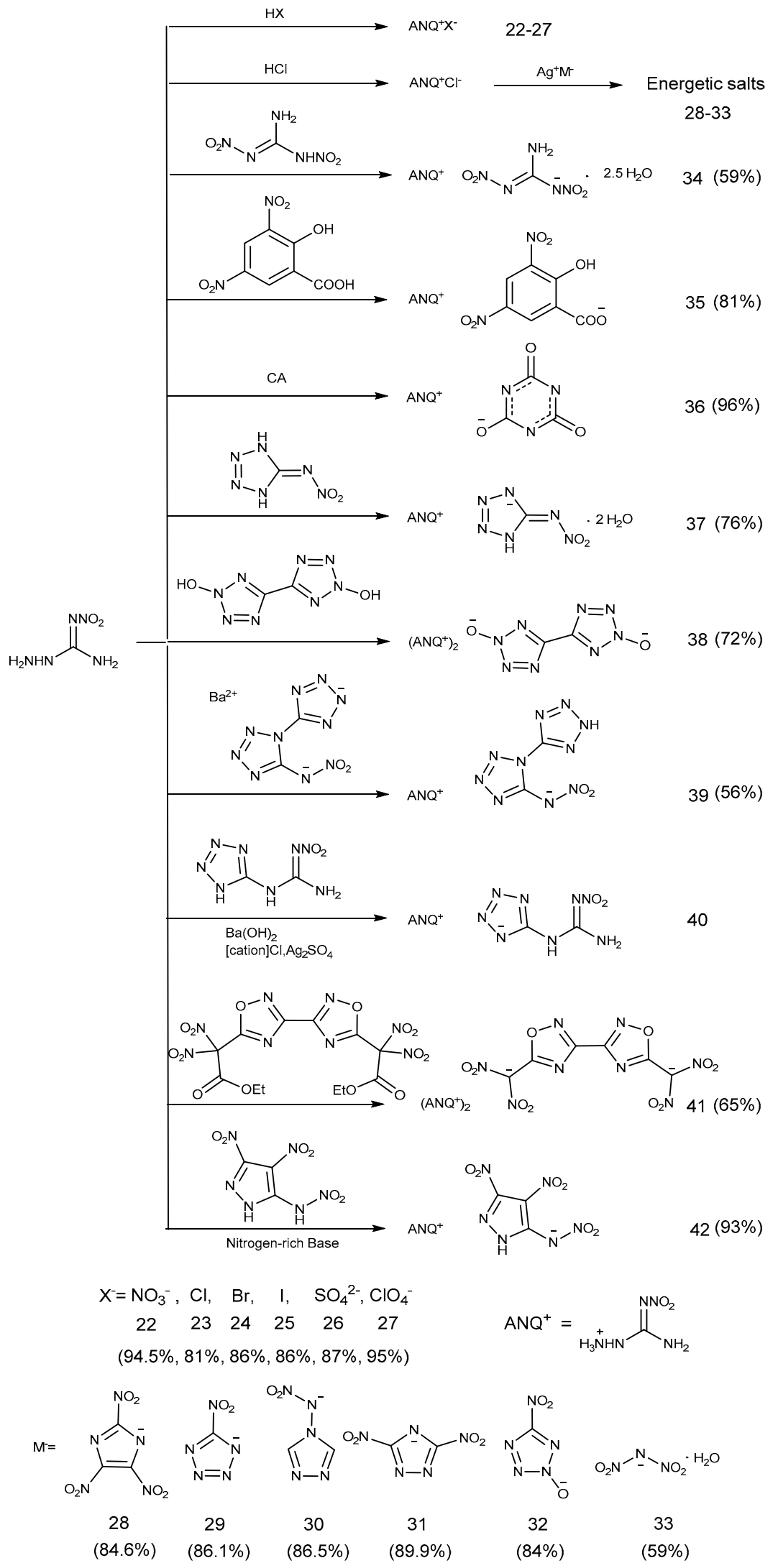

Scheme 10. Salification reaction of ANQ. 


\subsection{Coordination Reaction}

In 1928, Phillips firstly reported that ANQ reacted with nickel sulfate to form a nickel complex, which owned a high decomposition temperature of $220{ }^{\circ} \mathrm{C}$ [1]. ANQ can form energetic metal complexes $\left[\mathrm{M}^{2+}(\mathrm{ANQ})_{2}\left(\mathrm{X}^{-}\right)_{2}\left(\mathrm{H}_{2} \mathrm{O}\right)_{\mathrm{n}}(\mathrm{n}=0,2)\right.$, in the case of $\mathrm{M}=\mathrm{Co}, \mathrm{Ni}, \mathrm{Cu}, \mathrm{Zn}(43-46)$, and $\mathrm{M}^{+}(\mathrm{ANQ})_{2}\left(\mathrm{X}^{-}\right)\left(\mathrm{H}_{2} \mathrm{O}\right)_{\mathrm{y}}$ in the case of $\left.\mathrm{M}=\mathrm{Ag}(47)\right]$ with perchlorate or nitrate solution of transition metal [60]. Herein, nitrate, perchlorate and chloride are the anions of the complex, and ANQ is the ligand for the synthesis of high energy transition metal complexes, as seen in Scheme 11. Complexes $\mathrm{M}^{2+}(\mathrm{ANQ})_{2}\left(\mathrm{X}^{-}\right)_{2}\left(\mathrm{H}_{2} \mathrm{O}\right)_{4}(48,49)$ with $\mathrm{X}=\mathrm{N}\left(\mathrm{NO}_{2}\right)_{2}$ can be synthesized in the case of $\mathrm{M}=\mathrm{Co}$ and $\mathrm{Ni}$, in a stoichiometric ratio of perchlorate complexes of cobalt (nickel): Ammonium dinitramide (ADN) =1:2, as seen in Scheme 12 [60]. All those complexes containing perchlorate, nitrate and chloride crystallize as dihydrates, except silver complexes (47) are water free. Dinitramide crystallizes as tetrahydrate (48, 49), and most of the complexes containing crystal water can be dehydrated without decomposition. In these complexes, the nickel complex is the most stable, having the highest decomposition temperature of $250{ }^{\circ} \mathrm{C}$, while the copper and silver complexes decompose at a low temperature of about $77^{\circ} \mathrm{C}$. Compared with nitrates and ammonium dinitramide (ADN), the decomposition temperatures of chlorides and perchlorates tend to increase. Moreover, all the complexes present high impact and friction sensitivities, especially the solvate water free silver complex (47) and the copper nitrate complex [60]. ANQ can also have coordination reaction with cobalt (II), nickel (II), copper (II) and 2-hydroxybenzaldehyde or 4-(dimethylamino)benzaldehyde [61].

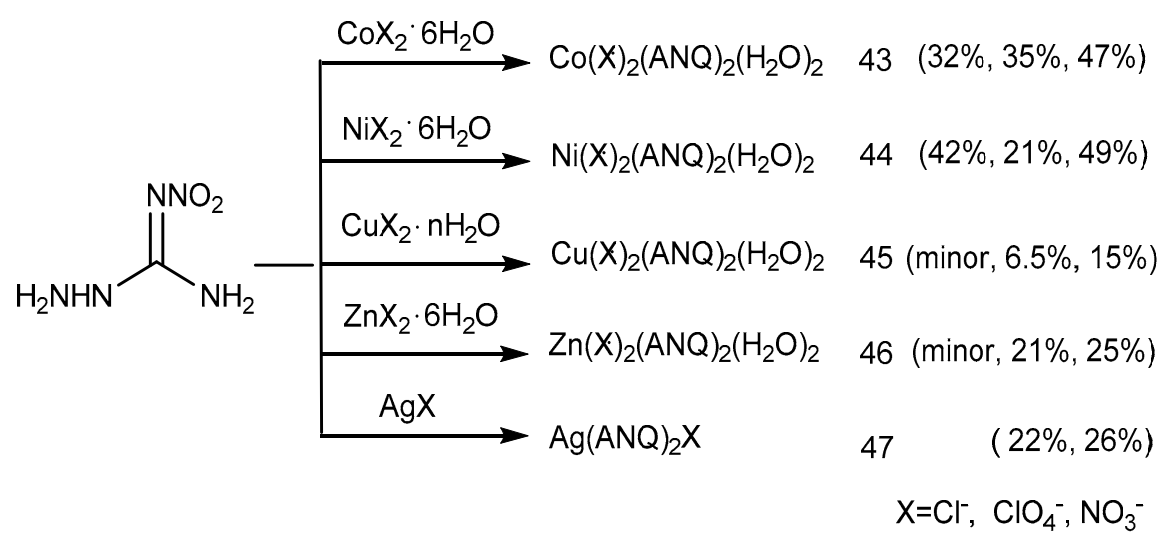

Scheme 11. Coordination reaction of ANQ.

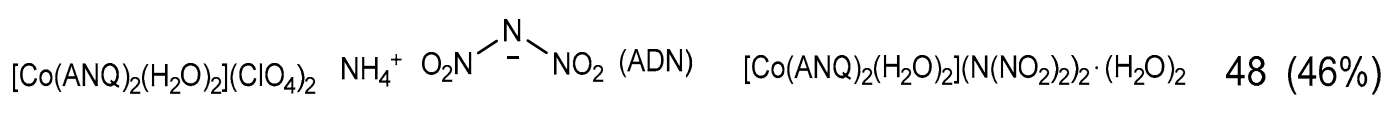

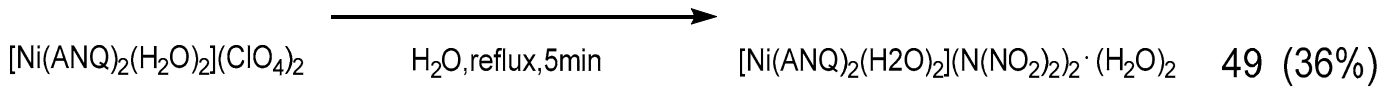

Scheme 12. Complicated coordination reaction of ANQ.

\subsection{Aldimine Condensation Reaction}

ANQ can undergo condensation reactions with aldehydes and ketones to form hydrazine or Schiff base compounds. Phillips found that ANQ can react with aldehydes and ketones by using an acid or a base as catalyst, as shown in Scheme 13 [1]. When an acid is used as catalyst, its hydrogen ion can be combined with a carbonyl group to form an oxonium salt, thereby increasing the electrophilicity of the carbonyl group [62]. The nucleophilic addition-elimination reaction mechanisms under acid-base conditions are shown in Schemes 14 and 15. 


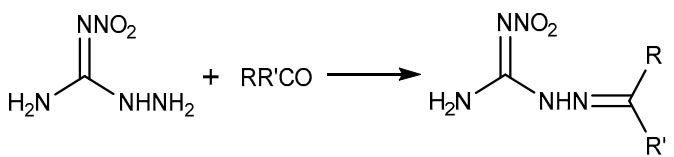

Scheme 13. Aldehyde ketone reaction of ANQ.

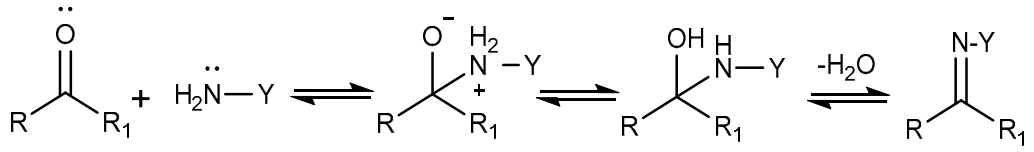

Scheme 14. Reaction mechanism of ANQ with aldehydes and ketones under acidic conditions.

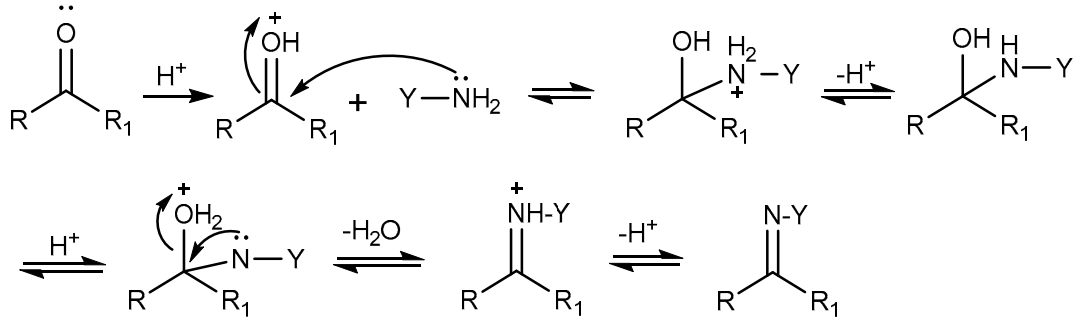

Scheme 15. Reaction mechanism of ANQ with aldehydes and ketones under alkaline conditions

ANQ reacted with 3-methyl-4-furoxancarbaldehyde and 2,4,6-trinitrobenzaldehyde leading to the formation of 3-methyl-4-((2-( $N^{\prime}$-nitrocarbamimidoyl)hydrazono)methyl)-1,2,5-oxadiazole-2- oxide (50) and $N^{\prime}$-nitro-2-(2,4,6-trinitrobenzylidene)hydrazinecarboximidamide (51), as seen in Scheme 16 [63]. Only hydrazino group of ANQ could react with aldehyde group, and no condensation reaction of amino group with aldehyde group was found. This may be because the strong electron-withdrawing effect of nitro group reduced the reactivity of amino group.

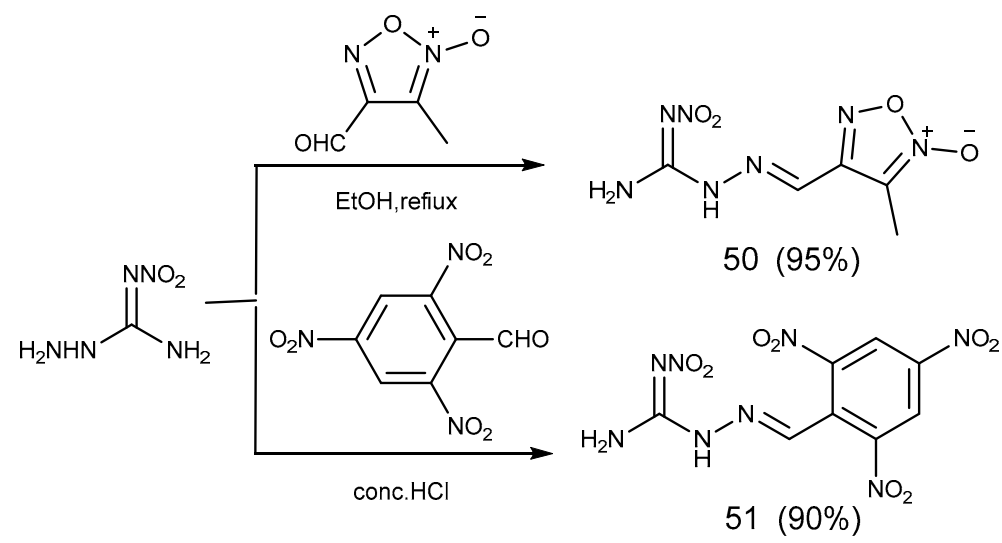

Scheme 16. Aldehyde ketone reaction of ANQ.

Additionally, the treatment of ANQ with formaldehyde resulted in the formation of 1-hydroxymethylamino-2-nitroguanidine (52). The terminal hydroxyl function of compound had high activity and could further react with nitroform in methanol, ethanol or water to obtain 2-nitro-1-(2,2,2-trinitroethylamino)guanidine (TNEANG) (53) [64,65]. Compound 53 was a typical trinitromethyl derivative, which could be reduced by iodide to form a potassium salt of 1-(2,2-dinitroethylamino)-2-nitroguanidine (54) [65]. It was also able to react with denitration agents such as $\mathrm{K}_{2} \mathrm{CO}_{3}$ or $\mathrm{KOH}$, followed by acidification with hydrochloric acid to obtain 1-(2,2-dinitroethylamino)-2-nitroguanidine (DNEANG) (55) containing a dinitromethyl structure. The separation phase of potassium salt 54 was successfully eliminated, increasing the yield of 55 from $44 \%$ to $78 \%$, as seen in Scheme 17 [53,64-67]. The detonation properties of TNEANG (53) and 
DNEANG (55) have not been reported, but their melting points are as low as $95-96{ }^{\circ} \mathrm{C}$ and $93-94{ }^{\circ} \mathrm{C}$ respectively, which are promising as melting phase for melt casting explosives [64].

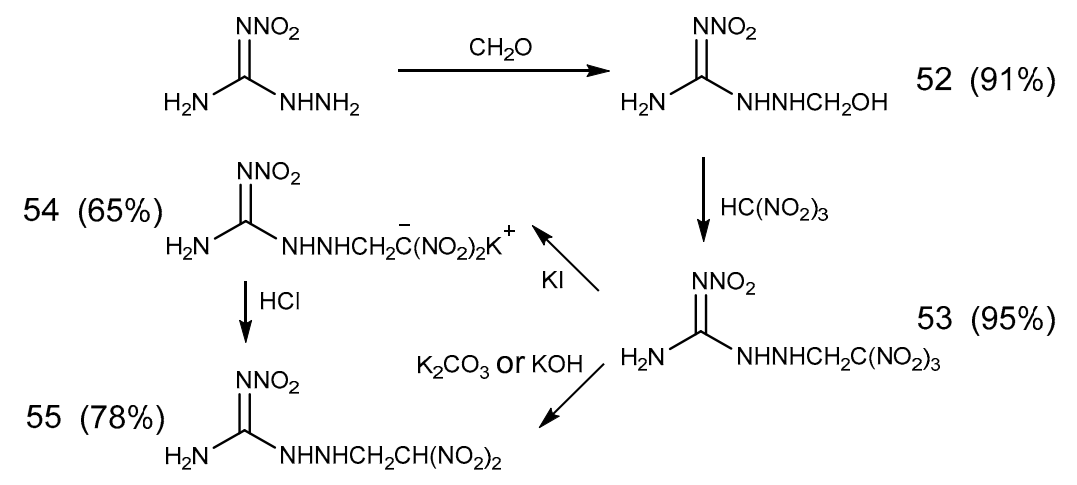

Scheme 17. Synthesis of 1-hydroxymethylamino-2-nitroguanidine and its derivatives.

Based on the reaction of nitroguanidine and formaldehyde to form methylene dinitroguanidine, our research group hoped that designing a route of linking two molecules of ANQ with methylene to synthesize a symmetric energetic compound 56 or 57, but failed even though various methods were attempted. However, methyleneaminonitroguanidine (MANG) (58), as shown in Scheme 18, was unexpectedly synthesized with a high yield of $86 \%$ [68]. The reason should be that the amino of the hydrazino group is more nucleophilic. The nucleophilic addition reaction firstly occurs since the positively charged carbon atom on the carbonyl group is attacked, and the resulting intermediate is further dehydrated to form MANG. This process is a classical aldimine condensation reaction. MANG crystallizes in the orthorhombic crystal system with space group $\mathrm{P}_{\mathrm{nn}} 2$ containing four molecules per unit cell. The crystal density is $1.63 \mathrm{~g} \mathrm{~cm}^{-3}$. Its impact sensitivity, detonation velocity and detonation pressure are $>7.9 \mathrm{~J}, 7.1 \mathrm{~km} \mathrm{~s}^{-1}$ and $20.9 \mathrm{GPa}$, respectively. In addition, we hoped to obtain a more stable five-membered nitrogen heterocyclic compound 59 through the cyclization reaction, but also failed. It illustrates that aldehyde ammonia condensation is more advantageous in this system, and it is difficult to undergo chain reaction and cyclization reaction [68].

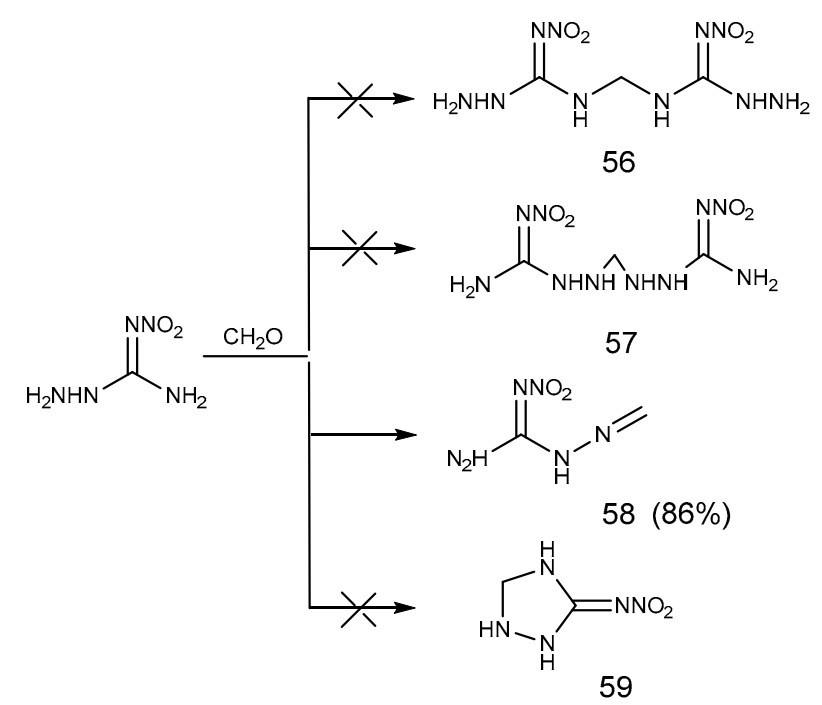

Scheme 18. Reaction of ANQ with formaldehyde.

Treatment of ANQ with glyoxal in sodium hydroxide solution led to a $N^{\prime}$-nitro-2-(2-oxoethylidene)hydrazinecarboximidamide (60) as a mixture of syn and anti-isomers (ratio of 1:1), as seen in Figure 4. When ANQ was 2-fold excess, $N^{\prime}$-nitro-2-[(5-nitroamino-2H-1,2,4-triazol-3-yl) 
methyl]hydrazinecarboximidamide (61) and 3-nitroamino-4,5-dihydro-1,2,4-triazin-5-ol (62) were formed. However, under acidic conditions, ANQ reacted with glyoxal to form glyoxal dihydrazone (63), which could also be synthesized by hydrazone 60 and ANQ in boiling glacial acetic acid for a long time [69,70], as seen in Scheme 19.<smiles>NC(=[W])N1N=CC=CO1</smiles><smiles>N/C(=N\O)N/N=C/C=O</smiles>

Figure 4. Syn-/anti-isomers of compound 60.

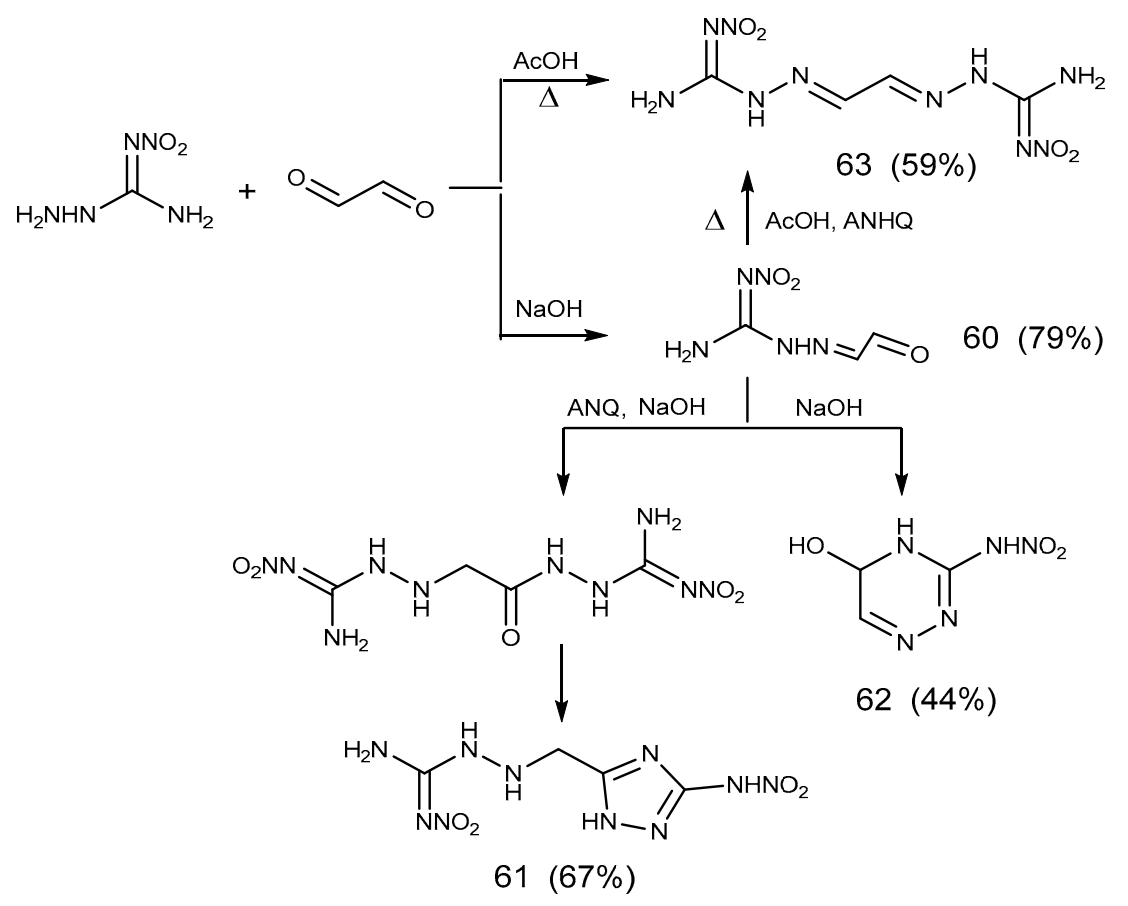

Scheme 19. Reaction of ANQ with glyoxal.

Under the catalysis of acid, a linear monohydrazone (64) was prepared by an equimolar ratio of ANQ and butane-2,3-dione. A 2-fold excess of ANQ was used to generate a 5:8 ratio of a mixture of monohydrazone (64) and dihydrazone (65) [71], as seen in Scheme 20. Similarly, ANQ reacted with acetylacetone to generate acetylacetonenitroguanylosazone [72].

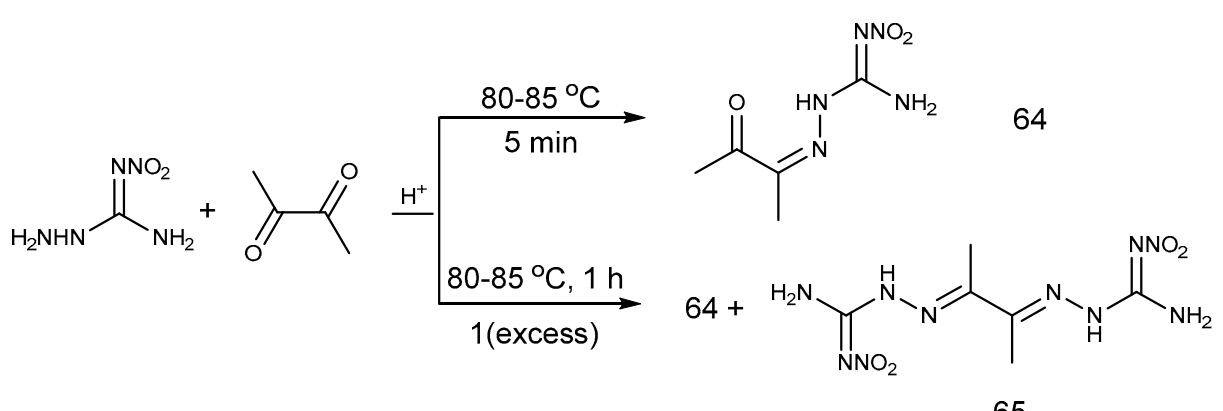

Scheme 20. Reaction of ANQ with butane-2,3-dione. 
Our group expected that ANQ reacts with trichlorotriazine in acetone to get 2,4,6-tris(1-amino-2-nitroguanidinium)-1,3,5-triazine (66), but failed. However, it was surprisingly found that ANQ directly reacted with acetone at $55^{\circ} \mathrm{C}$ for $6 \mathrm{~h}$ in the presence of trichlorotriazine, which may be catalyst, resulting in the formation of $N^{1}, N^{2}$-bis(2-nitroguanidinium)propane-1,2-diimine (DNPD, 67). We suspected that trichlorotriazine did not work in the reaction. So we designed the reaction of ANQ only with acetone in the absence of trichlorotriazine and obtained $N^{\prime}$-nitro-2-(propan-2-ylidene)hydrazine-1-carboximidamide (NPYHC, 68) successfully, which was a classic reaction of addition condensation reaction of ammonia and ketone. Therefore, trichlorotriazine should play a catalytic role in the reaction, as seen in Scheme 21.

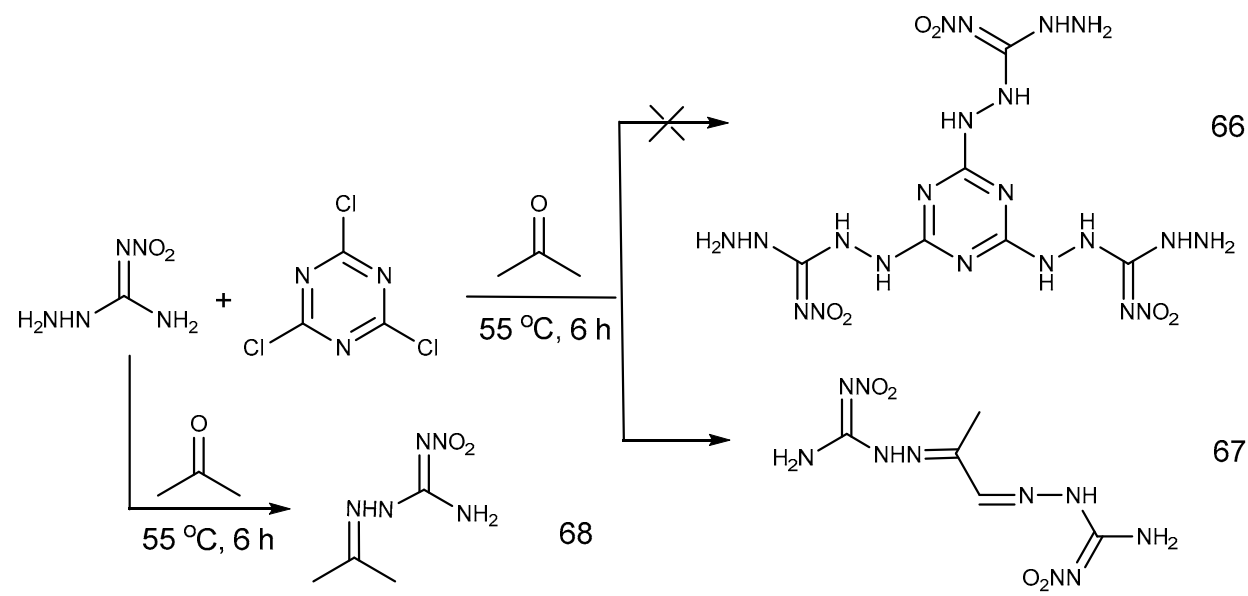

Scheme 21. Reaction of ANQ with acetone.

\subsection{Cyclization Reaction}

ANQ can undergo many cyclization reactions to synthesize corresponding azoles and azines under different conditions. Compared with traditional carbon-based high-energy compounds such as TNT and TATB, high-energy materials with high nitrogen heterocycles have more advantages, including higher molecular density, fine environmental compatibility and it is easier to achieve good oxygen balance. High nitrogen heterocyclic materials have higher energy and stability due to their high-energy $\mathrm{N}-\mathrm{N}, \mathrm{C}-\mathrm{N}, \mathrm{N}=\mathrm{N}$ bonds and molecular ring strain, so they are more widely used in energetic materials [73]. ANQ was reacted in $\mathrm{KNO}_{2} / \mathrm{AcOH}$ solution firstly, followed by acidifying it with hydrochloric acid to get 5-nitroaminotetrazole (69) which melts at $195^{\circ} \mathrm{C}$ and explodes at a slightly higher temperature [74,75]. 5-Nitroaminotetrazole is a superior precursor to energetic salts, and the derivatives of 69 have attracted much attention for their positive formation enthalpies and high nitrogen contents [76,77]. Compound 69 can be reduced with benzaldehyde in the presence of $\mathrm{Zn}$ to obtain a benzene derivative, or can be reacted with others to obtain corresponding tetrazole ammonium salt [78], diammonium salt [77], methylammonium salt [79], metal salts [80-82] (such as lithium salt, sodium salt, rubidium salt, cesium salt) and 1,2,4-triazolium salts [76]. Five different 1,2,4-triazolium salts were synthesized and shown in Scheme 22: 4-amino-1,2,4-triazolium (70), 5-amino-tetrazolium (71), 1,2,4-triazolium (72), 1-propyl-1,2,4-triazolium (73) and 3-azido-1,2,4-triazolium (74) [76]. Although compound 73 contains energetic anions, its low thermal stability $\left(T_{\mathrm{m}}=69^{\circ} \mathrm{C}\right)$ and density $\left(1.48 \mathrm{~g} \mathrm{~cm}^{-3}\right)$ restrict its practical applications. Compound 74 exhibits the highest heat of formation $(694.2 \mathrm{~kJ} \mathrm{~mol})$ and good detonation properties, but the triazolium derivative (72) has the highest density in this group compounds [76]. Compared with ordinary tetrazole ions, 5-nitroaminotetrazole is easier to form a corresponding complex with transition metal ions (such as $\mathrm{Cu}, \mathrm{Ni}, \mathrm{Pb}, \mathrm{Hg}$ and $\mathrm{Ag}$ ) [83,84]. These derivatives have potential applications in energetic materials, for instance, using as initiators of explosive materials. 


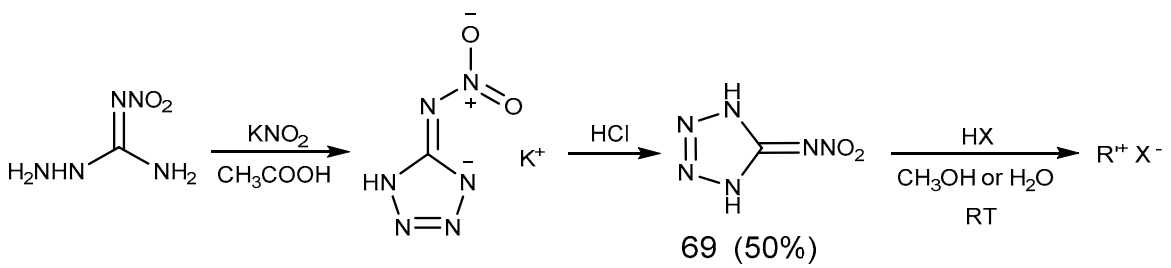<smiles>NN1CNNC1</smiles>

$70(98 \%)$<smiles></smiles>

$71(98 \%)$<smiles>C1CNCN1</smiles>

$72(98 \%)$<smiles>CCN1CNCN1</smiles><smiles>NC1NCNN1</smiles>

$73(98 \%) \quad 74(98 \%)$
$x^{-}=\prod_{\mathrm{NNO}_{2}}^{N}$

Scheme 22. Cyclization reaction of ANQ.

As long as the reaction temperature and reaction time were properly adjusted, 3,5-dimethyl- $\mathrm{N}$-nitro- $1 H$-pyrazole-1-carboxamidine (75) was formed by reaction of ANQ and pentane-2,4-dione, no matter in acidic or basic conditions [85,86], as seen in Scheme 23. However, ANQ reacted with butane-2,3-dione and 1,2-diphenylethanedione in acid or base conditions leading to different nitroamino products containing 1,2,4-triazine [71]. In water-alkaline solution, ANQ reacted with 2,3-butanedione to form 3-nitroamino-5,6-dimethyl-1,2,4-triazine (76) by heterocyclization at room temperature. It existed as a mixture of amine $\mathbf{7 6}$ and imine $\mathbf{7 7}$ tautomers in a DMSO- $d_{6}$ solution, as seen in Scheme 24. Additionally, compounds 64 and 65 were obtained under acidic conditions. In water-alcoholic solution, ANQ reacted with 1,2-diphenylethanedione to obtain 3-nitroamino-5,6-diphenyl-1,2,4-triazine (78) at $80{ }^{\circ} \mathrm{C}$ for $4.5 \mathrm{~h}$ under alkaline condition. When using an acid catalyst, 5-ethoxy-4,5-dihydro-(2H)-1,2,4-triazine (79) was separated, and the synthesis of 79 could be regarded as the result of the alkoxylation of the initially formed intermediate. Compound 79 was unstable and it could be converted to compound 78 by eliminating ethanol in DMSO- $d_{6}$ solution, as seen in Scheme 25 [71].

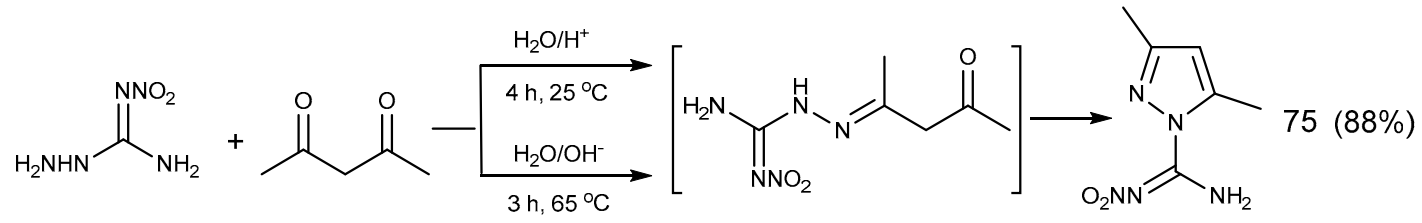

Scheme 23. Reaction of ANQ with pentane-2,4-dione.

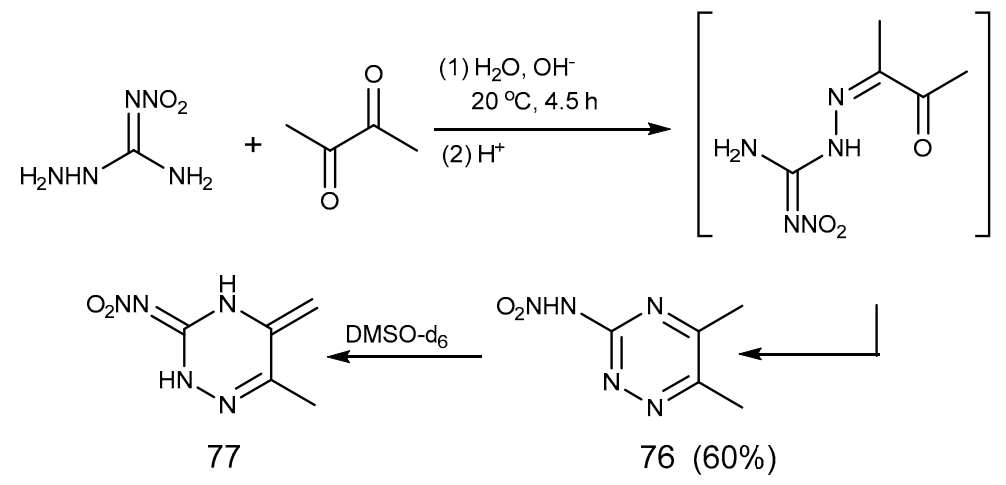

Scheme 24. Reaction of ANQ with butane-2,3-dione. 


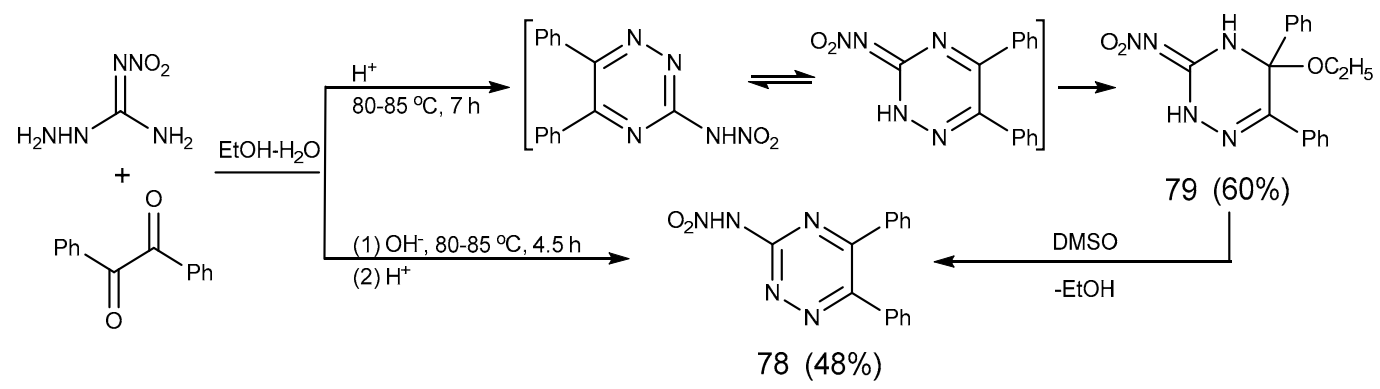

Scheme 25. Reaction of ANQ with 1,2-diphenylethanedione.

ANQ condensed with triethyl orthoformate to form 3-nitramino-1,2,4-triazole (80). When the dosage of orthoformate was reduced, the hydrazino group of ANQ was acetylated to form $\mathrm{N}$-acetyl-3-amino-1-nitroguandine (81). However, compound $\mathbf{8 1}$ was unstable and converted to another product easily. In the presence of sodium azide, 1-nitroguanidyltetrazole (82) was prepared by ANQ and triethyl orthoformate in glacial acetic acid medium [87], as seen in Scheme 26. Furthermore, the condensation reaction of ANQ with heterocyclic 3-(dinitromethyl)-1,2,4-triazine potassium salt could result in the corresponding compound, 3-nitrimino-7-dinitromethylene-octahydro-(1,2,4)triazino-(6,5-e) $(1,2,4)$ triazine $(83)$, as seen in Scheme 27. Its detonation properties $\left(P=29.4 \mathrm{GPa}, D=8.492 \mathrm{~km} \mathrm{~s}^{-1}\right)$ compare favorably with those of $\mathrm{ANQ}$, so it has potential application value in energetic materials [88].

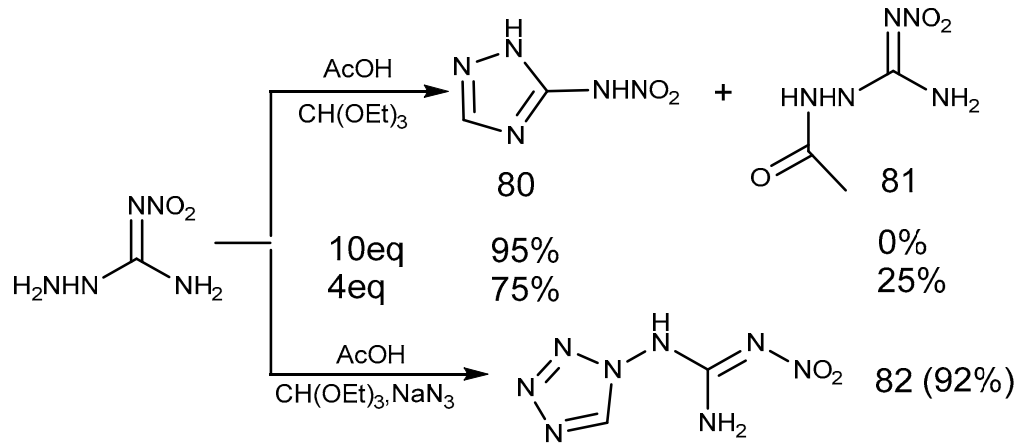

Scheme 26. Reaction of ANQ with triethyl orthoformate.<smiles>CC(C)(C)[N+](=O)[O-]</smiles>

Scheme 27. Reaction of ANQ with the derivative of FOX-7.

\subsection{Azide Reaction}

ANQ reacted in a strong acid solution of $\mathrm{HCl} / \mathrm{KNO}_{2}$ to obtain azide nitroguanidine (84) at $60{ }^{\circ} \mathrm{C}$ with the yield of $77 \%$ [75]. It was found that ANQ could react with nitrous acid in weak or strong acid solution to obtain azide nitroguanidine, and the yield in strong acid solution was higher. Compound 84 has a high nitrogen content $(64.62 \%)$ and presents a potential application value. It can be reduced to nitroguanidine by hydrogen sulfide, as a characteristic reaction of azide. Compound $\mathbf{8 4}$ was cyclized with inorganic base or organic base to obtain the corresponding alkyl or aryl ammonium salts of 5-nitroaminotetrazole (85-91), which could also be obtained directly by alkalizing 5-nitroaminotetrazole, as seen in Scheme 28 [74]. 

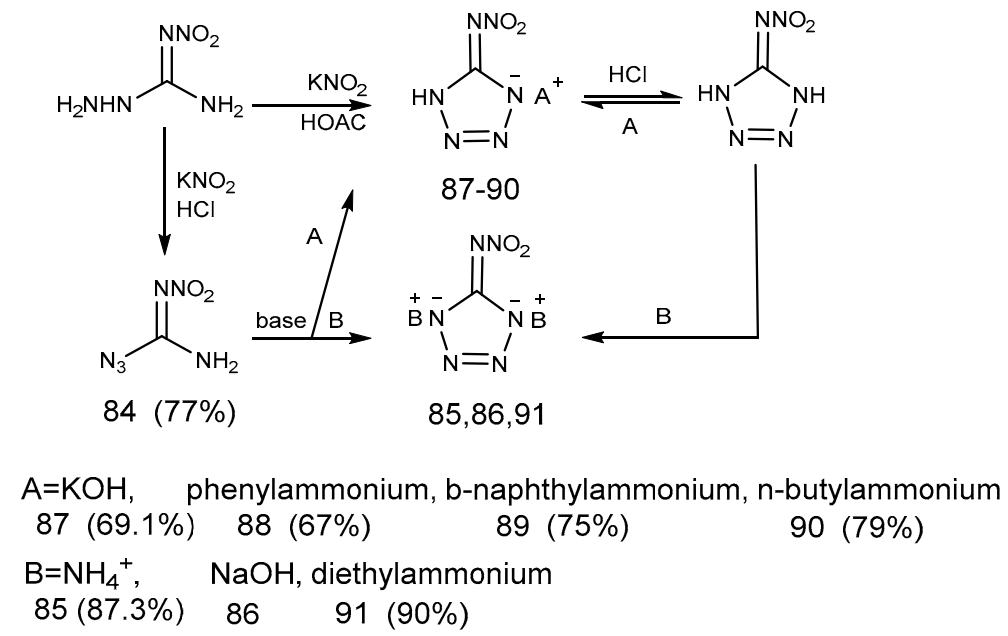

Scheme 28. Azide reaction of ANQ.

\subsection{Detonation Properties}

A series of derivatives of ANQ were summarized systemically and some compounds, as potential energetic materials, display good energetic properties, as shown in Table 2. We use the classification in "UN Recommendations on the Transport of Dangerous Goods" to evaluate their safety [89]. Compound 27 is the most sensitive compound with values of $1 \mathrm{~J}$ (IS) and $20 \mathrm{~N}$ (FS), which is classified as very sensitive. The other compounds except the compound 35 (>40 J) and 36 (>60 J) are sensitive. However, compounds 22, 33, 34, 38, 39, 41, 42, 58 and 83 exhibit impact sensitivities between 7-10 J, and they are comparable to or less sensitive than RDX. Compounds 50, 51, 67 and 68 are considerably less sensitivity than RDX, but similar to ANQ. Regarding the friction sensitivity some compounds follow the trends observed for the impact sensitivities, some do not. For example, compound 83 (>360 N) can be classified as an insensitive material to friction, and compounds 22, 26, 41, 50 and 51 have similar friction sensitivity to ANQ and RDX, but all of them have higher friction sensitivity than TNT. For compounds 23-25, even if they are less sensitive, the decomposition temperatures of them are only $80^{\circ} \mathrm{C}$, so they are of little value for energetic applications. The detonation pressures $(P)$ of these derivatives distribute in the range of $19.06-48.5 \mathrm{GPa}$, and their detonation velocities $\left(V_{\mathrm{det}}\right)$ are found in the range from 6.860 to $10.358 \mathrm{~km} \mathrm{~s}^{-1}$, most of which are between $8.230-9.551 \mathrm{~km} \mathrm{~s}^{-1}$. Compound 69 shows the highest detonation velocity $\left(10.358 \mathrm{~km} \mathrm{~s}^{-1}\right)$ and the highest detonation pressure (48.5 GPa), and the detonation velocities of its derivatives (70-74) are comparable to that of RDX. The detonation performances of compounds 22, 33, 38-42 and 69 exceed that of RDX except compound 40. Compound 35, 50, 58 and 68 reach the energy level of RDX, and all of the other compounds show comparable or superior detonation velocities to that of ANQ. Compound $30(P=26.6$ GPa and $\left.V_{\text {det }}=8.050 \mathrm{~km} \mathrm{~s}^{-1}\right), 35\left(P=23.4 \mathrm{GPa}\right.$ and $\left.V_{\text {det }}=7.500 \mathrm{~km} \mathrm{~s}^{-1}\right)$ and $58(P=20.9 \mathrm{GPa}$ and $V_{\text {det }}=7.100 \mathrm{~km} \mathrm{~s}^{-1}$ ) possess relatively poor detonation performances for their lower densities of $1.59-1.63 \mathrm{~g} \mathrm{~cm}^{-3}$ compared to the other compounds $\left(1.70-2.06 \mathrm{~g} \mathrm{~cm}^{-3}\right)$, supporting the view that high density contributes markedly to the detonation performances. In summary, the compounds, 22, 33, 38-42 and 69 exhibit good detonation properties, and can be regarded as potential candidates in the application of high-energy-density materials. 
Table 2. Physical and energetic properties of some derivatives of ANQ.

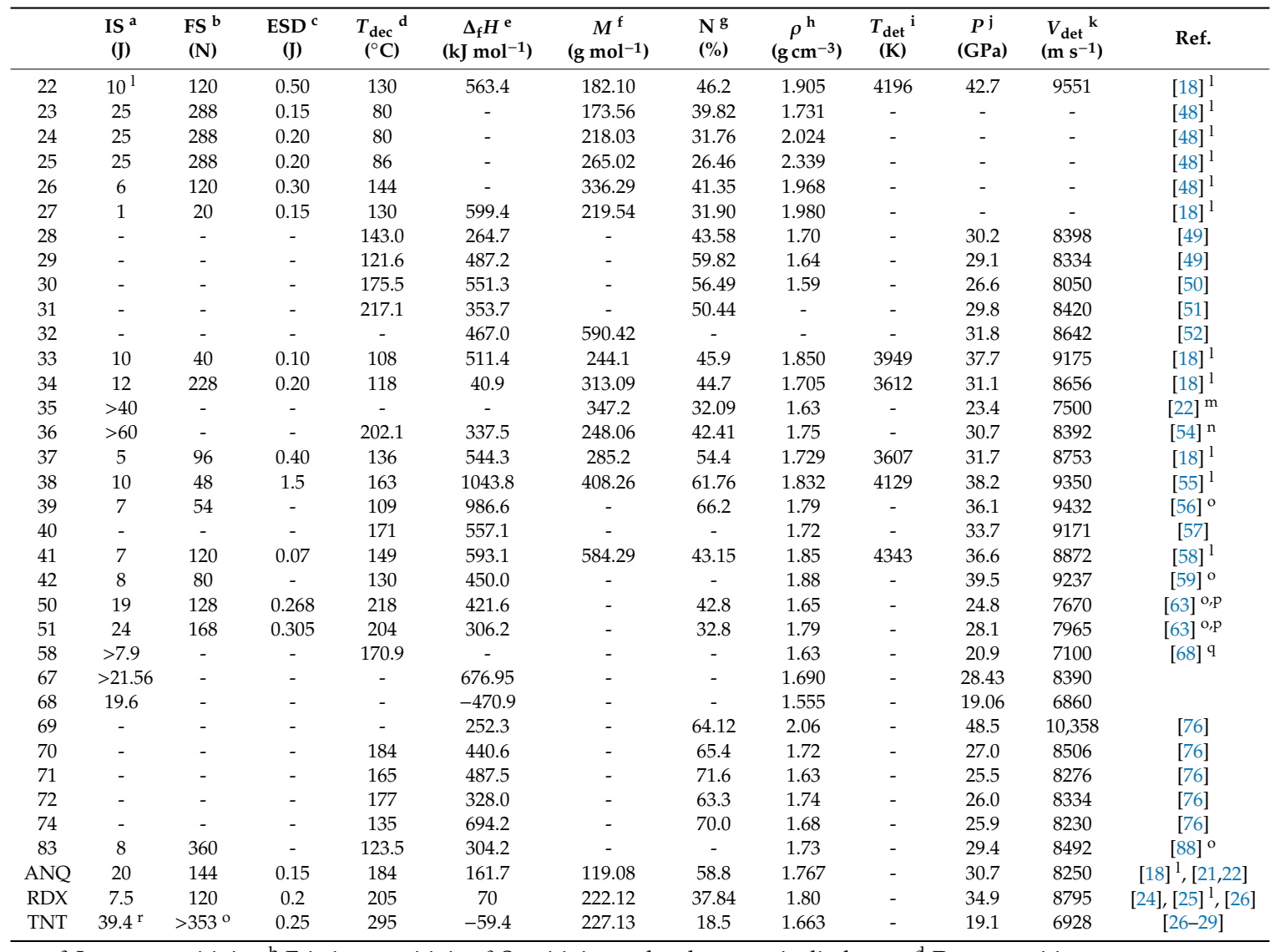

${ }^{a}$ Impact sensitivity. ${ }^{b}$ Friction sensitivity. ${ }^{c}$ Sensitivity to the electrostatic discharge. ${ }^{\mathrm{d}}$ Decomposition temperature. ${ }^{\mathrm{e}}$ Molar enthalpy of the formation of compound. ${ }^{\mathrm{f}}$ Molecular mass. ${ }^{\mathrm{g}}$ Nitrogen content. ${ }^{\mathrm{h}}$ Crystal density. ${ }^{\mathrm{i}}$ Explosion temperature. ${ }^{j}$ Detonation pressure. ${ }^{k}$ Detonation velocity. ${ }^{1}$ IS: STANAG 4489 modified instructions, BAM Drop Hammer; FS: STANAG 4487 modified instructions, BAM friction tester; ESD: OZM, the Electric Spark Tester ESD 2010 EN. ${ }^{m}$ IS: ZBL-B impact sensitivity instrument, 2.0 kg Drop Hammer. ${ }^{n}$ IS: 5.0 kg Drop Hammer. ${ }^{\circ}$ IS: standard BAM Fall Hammer; FS: BAM friction tester. P ESD: Electric Spark Tester ESD JGY-50 III. ${ }^{\mathrm{q}}$ IS: 5.0 kg Drop Hammer.

${ }^{\mathrm{r}}$ IS: h50 of $160 \mathrm{~cm}, 2.5 \mathrm{~kg}$ Hammer.

\section{Conclusions}

Since the first report, ANQ has been regarded as an important raw material in the fields of pesticides, medicines and energetic materials. As a high-energy insensitive material, ANQ is likely to replace traditional RDX in application of solid propellants.

Though the molecular structure is very simple, its reactivity is abundant. Seven kinds of reactions about ANQ are systematically summarized, including reduction reaction, acylation reaction, salification reaction, coordination reaction, aldimine condensation reaction, cyclization reaction and azide reaction. Many excellent derivatives have been synthesized by these reactions. Some high-energy nitrogen-rich derivatives, such as ANGN, 1-amino-2-nitroguanidinium 5,5'-bis(tetrazole-2-oxide) salt and 5-nitroaminotetrazole, exhibit a good application prospect in the field of energetic materials.

According to the summary of the reactivity for ANQ, we can see that the adjacent amino and hydrazino group is a high activity group and the key factor for synthesizing these derivatives, especially to the heterocyclic derivatives. Therefore, in the design of nitrogen-rich or heterocyclic compounds, the introduction of the adjacent amino and hydrazino group is an effective way. We believe that many new nitrogen-rich materials can be synthesized according this method. The research of the reactivity of ANQ contributes significantly to expanding the understanding of the chemistry of guanidine compounds.

Author Contributions: Writing—original draft preparation, J.W. and M.C.; writing-review and editing, J.W., M.C. and K.X.; supervision, K.X. and F.Z. 
Funding: This investigation received financial assistance from the National Natural Science Foundation of China (21673178), the Natural Science Foundation of Shaanxi Province (2018JM5181), and the National Defense Scientific Research Project.

Conflicts of Interest: The authors declare no conflict of interest.

\section{References}

1. Phillips, R.; Williams, J.F. Nitro-Aminoguanidine. J. Am. Chem. Soc. 1928, 50, 2465-2470. [CrossRef]

2. Yaginuma, S.; Asahi, A.; Takada, M.; Hayashi, M.; Fukukawa, K. Synthesis or Isolation of Estatin A and Estatin B and Their Use as Enzyme Inhibitors. US Patent 4732910, 22 March 1988.

3. Qin, Z.H.; Ma, Y.Q.; Su, W.C.; Zhao, B.B.; Fang, J.S. 2,5-Disubstituted-3-Nitroimino-1,2,4-Triazolines as Insecticide and Their Preparation. WO Patent 2013003977, 10 January 2013.

4. Qin, Z.H.; Ma, Y.Q.; Su, W.C.; Wang, L.; Zhang, Z.; Zhao, B.B.; Fang, J.S. Preparation of Condensed 1-Amino-2-Nitroguanidine Compounds as Botanical Insecticides. US Patent 20110306639, 15 December 2011.

5. Liberatore, A.M.; Bigg, D.; Pons, D.; Prevost, G. New 2-(Phenoxymethyl)-4-(Phenoxyphenyl)-1H-Imidazole Derivatives, Their Preparation, and Their Use as Inhibitors of Tubulin Polymerization for Treating Neoplasm. US Patent 8188133, 29 May 2012.

6. Westphal, G.; Scheybal, A.; Lipke, B.; Weber, F.G. Preparation of Several 3-Hetaryl-2- Quinoxalinones. Pharmazie 1977, 32, 563-565.

7. Efimova, T.P.; Ozerova, O.Y.; Belik, I.V.; Novikova, T.A.; Berestovitskaya, V.M. $\beta$-Nitro- and $\beta$-Bromo- $\beta$-nitrostyrenes in the Reactions with Aminonitroguanidine. Russ. J. Gen. Chem. 2012, 82, 1409-1415. [CrossRef]

8. Bierowska-Charytonowicz, D.; Konieczny, M. Search for New Aminoguanidine Derivatives with Immunosuppressive and Cytostatic Properties. I. Reactions of Amino-, Nitroamino- and Diaminoguanidine with Acetylpyruvic Acid Ethyl Ester. Arch. Immunol. Ther. Exp. 1976, 24, 871-881.

9. Efimova, T.P.; Ozerova, O.Y.; Novikova, T.A.; Baichurin, R.I.; Berestovitskaya, V.M. Reactions of 1-Amino-2-nitroguanidine with 2-Aryl(hetaryl)-1-nitro-1-ethoxycarbonyl (benzoyl)ethenes. Russ. J. Gen. Chem. 2014, 84, 1496-1499. [CrossRef]

10. Sun, C.W.; Wang, H.F.; Zhu, J.; Yang, D.R.; Jin, J.; Xing, J.H. Synthesis, Insecticidal Activities, and Molecular Docking Studies of 1,5-Disubstituted-1,3,5-hexahydrotriazine-2-(N-nitro)imines. J. Heterocycl. Chem. 2011, 48, 829-835. [CrossRef]

11. Su, W.C.; Zhou, Y.H.; Ma, Y.Q.; Wang, L.; Zhang, Z.; Rui, C.H.; Duan, H.X.; Qin, Z.H. $N^{\prime}$-Nitro-2-hydrocarbylidenehydrazinecarboximidamides: Design, Synthesis, Crystal Structure, Insecticidal Activity, and Structure-Activity Relationships. J. Agric. Food Chem. 2012, 60, 5028-5034. [CrossRef] [PubMed]

12. Berestovitskaya, V.M.; Ozerova, O.Y.; Efimova, T.P.; Gurzhiy, V.V.; Novikova, T.A. A New Synthesis of a Nitroimino-Containing 1,2,4-Triazin-5-one from 3-Bromo-3-nitropropenoates. Mendeleev Commun. 2016, 26, 323-325. [CrossRef]

13. Serebryannikova, A.V.; Lapshina, L.V.; Efremova, I.E.; Gurzhiy, V.V.; Ryabinin, A.E. 2-Benzylidene-3-methyl-4-nitro-3-thiolene-1,1-dioxide and its Analogs in Aza-Michael Reaction. Russ. J. Gen. Chem. 2018, 88, 1612-1617. [CrossRef]

14. Sorba, G.; Fruttero, R.; Calvino, R.; Gasco, A.; Orsetti, M. Potential Histamine $\mathrm{H}_{2}$-Receptor Antagonists: Ranitidine Analogues Containing "Semicarbazono Equivalent" Groups. Arch. Pharm. 1984, 317, 496-501. [CrossRef]

15. Vaillancourt, V.A.; Larsen, S.D.; Tanis, S.P.; Burr, J.E.; Connell, M.A.; Cudahy, M.M.; Evans, B.R.; Fisher, P.V.; May, P.D.; Meglasson, M.D.; et al. Synthesis and Biological Activity of Aminoguanidine and Diaminoguanidine Analogues of the Antidiabetic/Antiobesity Agent 3-Guanidinopropionic Acid. J. Med. Chem. 2001, 44, 1231-1248. [CrossRef] [PubMed]

16. Berestovitskaya, V.M.; Ozerova, O.Y.; Efimova, T.P.; Novikova, T.A. Reaction of 2,3-Dibromo-3-nitroacrylates with $N$-amino- $N^{\prime \prime}$-nitroguanidine. Russ. J. Org. Chem. 2015, 51, 1797-1798. [CrossRef]

17. Klapötke, T.M.; Stierstorfer, J. Current Advances in RDX Replacements. II. In Proceedings of the 27th Army Science Conference, Orlando, FL, USA, 29 November-2 December 2010.

18. Fischer, N.; Klapötke, T.M.; Stierstorfer, J. 1-Amino-3-nitroguanidine (ANQ) in High- Performance Ionic Energetic Materials. Z. Naturforsch. B A J. Chem. Sci. 2012, 67, 573-588. [CrossRef] 
19. Li, Y.F. Synthesis, Characterization and Thermal Behavior of ANQ Derivatives (in Chinese). Master's Dissertation, Northwest University, Xi'an, China, 2017.

20. Li, Y.F.; Wang, M.J.; Xu, K.Z.; Song, J.R.; Zhao, F.Q. Thermal Behaviors of 1-Amino- 2-nitroguanidine. Chin. J. Energ. Mater. 2016, 24, 848-852.

21. Licht, H.H.; Ritter, H.; Wanders, B. Novel explosives: Nitrotriazoles. Syntheses and Explosive Properties. In Proceedings of the 25th International Annual Conference of ICT, Weil am Rhein, Germany, 28 June-1 July 1994.

22. Feng, Z.C.; Guan, X.G.; Xu, K.Z.; Zhai, L.J.; Zhao, F.Q. Three New Energetic Compounds Based on 1-Amino-2-nitroguanidine (ANQ): Synthesis, Crystal Structure and Properties. J. Mol. Struct. 2018, 1166, 369-376. [CrossRef]

23. Koch, E.C. Insensitive High Explosives: III. Nitroguanidine-Synthesis-Structure- Spectroscopy-Sensitiveness. Propellants Explos. Pyrotech. 2019, 44, 267-292. [CrossRef]

24. Wharton, R.K.; Chapman, D. The Relationship between BAM Friction and Rotary Friction Sensitiveness Data for High Explosives. Propellants Explos. Pyrotech. 1997, 22, 71-73. [CrossRef]

25. Klapötke, T.M.; Penger, A.; Pflüger, C.; Stierstorfer, J.; Sućeska, M. Advanced Open-Chain Nitramines as Energetic Materials: Heterocyclic-Substituted 1,3-Dichloro-2-nitrazapropane. Eur. J. Inorg. Chem. 2013, 2013, 4667-4678. [CrossRef]

26. Tang, Y.X.; Gao, H.X.; Parrish, D.A.; Shreeve, J.M. 1,2,4-Triazole Links and N-Azo Bridges Yield Energetic Compounds. Chem. Eur. J. 2015, 21, 11401-11407. [CrossRef]

27. Szala, M.; Sabatini, J.J. 2,4,6-Trinitrotoluene-A Useful Starting Compound in the Synthesis of Modern Energetic Compounds. Z. Anorg. Allg. Chem. 2018, 644, 262-269. [CrossRef]

28. Xiang, D.L.; Rong, J.L.; He, X. Detonation Performance of Four Groups of Aluminized Explosives. Cent. Eur. J. Energ. Mater. 2016, 13, 903-915. [CrossRef]

29. Storm, C.B.; Stine, J.R.; Kramer, J.F. Sensitivity Relationships in Energetic Materilas. In Chemistry and Physics of Energetic Materials; Bulusu, S.N., Ed.; NATO ASI Series; Kluwer Acad. Publishers: Dordrecht, The Netherlands, 1990.

30. Latypov, N.V.; Bergman, J. Synthesis and Reactions of 1,1-Diamino-2,2-dinitroethylene. Tetrahedron 1998, 54, 11525-11536. [CrossRef]

31. Viswanath, D.S.; Ghosh, T.K.; Boddu, V.M. Emerging Energetic Materials: Synthesis, Physicochemical, and Detonation Properties. In FOX-7 (1,1-Diamino-2,2-Dinitroethylene); Springer Nature: New York, NY, USA, 2018.

32. Bemm, U.; Ostmark, H. 1,1-Diamino-2,2-dinitroethylene: A Novel Energetic Material with Infinite Layers in Two Dimensions. Acta Cryst. 1998, C54, 1997-1999. [CrossRef]

33. Talawar, M.B.; Sivabalan, R.; Anniyappan, M.; Gore, G.M.; Asthana, S.N.; Gandhe, B.R. Emerging Trends in Advanced High Energy Materials. Combust. Explos. Shock Waves 2007, 43, 62-72. [CrossRef]

34. Zhang, Y.; Sun, Q.; Xu, K.Z.; Song, J.R.; Zhao, F.Q. Review on the Reactivity of 1,1- Diamino-2,2-dinitroethylene (FOX-7). Propellants Explos. Pyrotech. 2016, 41, 35-52. [CrossRef]

35. Castillo-Meléndez, J.A.; Golding, B.T. Optimisation of the Synthesis of Guanidines from Amines via Nitroguanidines Using 3,5-Dimethyl-N-nitro-1H-pyrazole-1-carboxamidine. Synthesis 2004, 10, 1655-1663. [CrossRef]

36. Mckay, A.F. Nitroguanidines. Chem. Rev. 1952, 51, 301-346. [CrossRef]

37. Metelkina, E.L. 2-Nitroguanidine Derivatives: VI. Synthesis and Chemical Properties of Hydrazo- and Azobis(nitroformamidine). Russ. J. Org. Chem. 2004, 40, 928-935. [CrossRef]

38. Astrat'yev, A.A.; Dashko, D.V.; Kuznetsov, L.L. Synthesis and Some Properties of 1,2- Dinitroguanidine. Russ. J. Org. Chem. 2003, 39, 501-512. [CrossRef]

39. Astakhov, A.M.; Vasil'ev, A.D.; Gelemurzina, I.V.; Sokolenko, V.A.; Kruglyakova, L.A.; Stepanov, R.S. N-Nitroimines: I. Synthesis, Structure, and Properties of 3,5-Diamino-1- nitroamidino-1,2,4-triazole. Russ. J. Org. Chem. 2003, 39, 120-124. [CrossRef]

40. Jia, S.Y.; Bi, F.Q.; Wang, B.Z.; Li, Z.X.; Huo, H. Method for Synthesizing 1-Amino-3-nitroguanidine (in Chinese). CN Patent 105503661, 20 April 2016.

41. Kumler, W.D.; Sah, P.P.T. The Structure of Nitroguanidine and Nitroaminoguanidine. J. Org. Chem. 1953, 18, 669-675. [CrossRef] 
42. Hall, L.M.; Devries, J.E.; Gantz, E.S.C. Basic Equilibrium Constants of Nitroguanidine and Nitroaminoguanidine. J. Am. Chem. Soc. 1955, 77, 6507-6508. [CrossRef]

43. Lieber, E.; Sherman, E.; Patinkin, S.H. Ultraviolet Absorption Spectra of 5-Nitroaminotetrazole and its Salts. J. Am. Chem. Soc. 1951, 73, 2329-2331. [CrossRef]

44. Henry, R.A. Some Derivatives of Nitroguanidine. J. Am. Chem. Soc. 1950, 72, 5343-5345. [CrossRef]

45. Lieber, E.; Schiff, S.; Henry, R.A.; Finnegan, W.G. Acetylation and Ring Closure in Reduction of Nitro- and Nitroaminoguanidine. J. Org. Chem. 1953, 18, 218-228. [CrossRef]

46. Metelkina, E.L.; Novikova, T.A.; Berdonosova, S.N.; Berdonosov, D.Y. 2-Nitroguanidine Derivatives: IX. Reaction of 1-Amino-2-nitroguanidine with Oxalic Acid as a Method of Synthesis of 3(5)-Nitroamino-1,2,4-triazole-5(3)-carboxylic Acid and 5,5'-Bi(3-nitroamino-1, 2,4-triazole) Salts. Russ. J. Org. Chem. 2005, 41, 440-443. [CrossRef]

47. Jin, X.H.; Hu, B.C.; Liu, Z.L.; Lv, C.X. Structure and Properties of 1-Amino-2-Nitroguanidinium nitrate. RSC Adv. 2014, 4, 23898-23903. [CrossRef]

48. Fischer, N.; Klapötke, T.M.; Lux, K.; Martin, F.A.; Stierstorfer, J. Inorganic Amino-Nitro- Guanidinium Derivatives. Crystals 2012, 2, 675-689. [CrossRef]

49. Jin, X.H.; Hu, B.C.; Liu, Z.L. Synthesis and Properties of Two Energetic Salts Based on 1-Amino-2-nitroguanidine. J. Braz. Chem. Soc. 2015, 26, 124-130. [CrossRef]

50. Jin, X.H.; Hu, B.C.; Liu, Z.L.; Lv, C.X. Synthesis and Properties of 1-Amino-2- nitroguanidine 4-Nitramino-1,2,4-triazole Salt (in Chinese). Chin. J. Energ. Mater. 2015, 23, 213-217.

51. Jin, X.H.; Hu, B.C. Synthesis and Properties of 1-Amino-2-nitroguanidine 3,5-Dinitro-1,2,4- triazole Salt (in Chinese). J. QiLu. Uni. Technol. 2016, 30, 20-25.

52. Gao, S.J. Spheroidization of Nitroguanidine and Synthesis of its Derivatives (in Chinese). Master's Dissertation, Nanjing University of Science and Technology, Nanjing, China, 2015.

53. Jin, X.H. Design, Synthesis and Properties of Nitroguanidine-derived Energetic Compounds (in Chinese). Doctoral Dissertation, Nanjing University of Science and Technology, Nanjing, China, 2015.

54. Liu, Q.Q.; Jin, B.; Peng, R.F.; Guo, Z.C.; Zhao, J.; Zhang, Q.C.; Shang, Y. Synthesis, Characterization and Properties of Nitrogen-rich Compounds based on Cyanuric Acid: A Promising Design in the Development of New Energetic Materials. J. Mater. Chem. A 2016, 4, 4971-4981. [CrossRef]

55. Fischer, N.; Gao, L.; Klapötke, T.M.; Stierstorfer, J. Energetic Salts of 5,5'-Bis(tetrazole-2- oxide) in a Comparison to 5,5'-Bis(tetrazole-1-oxide) Derivatives. Polyhedron 2013, 51, 201-210. [CrossRef]

56. Wang, B.S.; Qi, X.J.; Zhang, W.Q.; Wang, K.C.; Li, W.; Zhang, Q.H. Synthesis of 1-(2HTetrazol-5-yl)-5-Nitraminotetrazole and its Derivatives from 5-Aminotetrazole and Cyanogen Azide: A Promising Strategy Towards Development of C-N Linked Bistetrazolate Energetic Materials. J. Mater. Chem. A 2017, 5, 20867-20873. [CrossRef]

57. Wang, R.H.; Guo, Y.; Zeng, Z.; Shreeve, J.M. Nitrogen-rich Nitroguanidyl-Functionalized Tetrazolate Energetic Salts. Chem. Commun. 2009, 19, 2697-2699. [CrossRef] [PubMed]

58. Klapötke, T.M.; Mayr, N.; Stierstorfer, J.; Weyrauther, M. Maximum Compaction of Ionic Organic Explosives: Bis(hydroxylammonium) 5,5'-Dinitromethyl-3,3'-bis(1,2,4-oxadiazolate) and its Derivatives. Chem. Eur. J. 2014, 20, 1410-1417. [CrossRef] [PubMed]

59. Yin, P.; Parrish, D.A.; Shreeve, J.M. Energetic Multifunctionalized Nitraminopyrazoles and Their Ionic Derivatives: Ternary Hydrogen-Bond Induced High Energy Density Materials. J. Am. Chem. Soc. 2015, 137, 4778-4786. [CrossRef] [PubMed]

60. Fischer, N.; Joas, M.; Klapootke, T.M.; Stierstorfer, J. Transition Metal Complexes of 3-Amino-1-nitroguanidine as Laser Ignitible Primary Explosives: Structures and Properties. Inorg. Chem. 2013, 52, 13791-13802. [CrossRef] [PubMed]

61. Gerasimchuk, A.I.; Mazurenko, Y.A. Metallochelates of Cobalt(II), Nickel(II), and Copper(II) with Salicylideneand Dimethylaminobenzylidenenitroaminoguanidine. Ukr. Khim. Zh. (Russian Edition) 2004, 70, 21-25.

62. Xing, Q.Y. Nucleophilic Addition and Conjugate Addition of Aldehydes and Ketones (in Chinese). In Basic Organic Chemistry; Higher Education Press: Beijing, China, 2007; p. 107.

63. Wu, B.; Yang, H.W.; Tang, Y.X.; Wang, Z.X.; Lu, C.X.; Cheng, G.B. New Energetic Derivatives of 1-Amino-3-Nitroguanidine. J. Energ. Mater. 2015, 33, 180-190. [CrossRef]

64. Metelkina, E.L.; Novikova, T.A.; Telenyuk, S.E. 2-Nitroguanidine Derivatives. Part 3. Study of Reaction Between 1-Amino-2-nitroguanidine and Formaldehyde. Russ. J. Org. Chem. 1999, 35, 1587-1589. [CrossRef] 
65. Metelkina, E.L.; Novikova, T.A. 2-Nitroguanidine Derivatives. Synthesis and Structure of 1-(2,2,2-Trinitroethylamino)- and 1-(2,2-Dinitroethylamino)-2-nitroguanidines. Russ. J. Org. Chem. 2002, 38, 1378-1379. [CrossRef]

66. Zhang, G.Q.; Liu, X.B.; Huang, M. Research Progress of Energetic Nitroguanidine Derivatives. J. Energ. Mater. 2013, 5, 668-674.

67. Glover, D.J.; Kamlet, M.J. Reaction of Trinitromethyl Compounds with Potassium Iodide. J. Org. Chem. 1961, 26, 4734-4735. [CrossRef]

68. Yang, H.; Feng, Z.C.; Guan, X.G.; Xu, K.Z.; Song, J.R.; Zhao, F.Q. Crystal Structure and Thermal Behavior of Methyleneaminonitroguanidine (MANG) (in Chinese). Chin. J. Energ. Mater. 2019, 27, 125-130.

69. Ozerova, O.Y.; Efimova, T.P.; Novikova, T.A.; Berestovitskaya, V.M. Reactions of 1-Amino-2-nitroguanidine with Glyoxal. Russ. J. Gen. Chem. 2015, 85, 2583-2591. [CrossRef]

70. Metelkina, E.L. 2-Nitroguanidine Derivatives: XI. Reactions of $N^{\prime}$-Nitrohydrazine carboximidamide and 2-Methylidene- $N^{\prime}$-nitrohydrazinecarboximidamide with Glyoxal. Russ. J. Org. Chem. 2008, 44, 495-498. [CrossRef]

71. Ozerova, O.Y.; Efimova, T.P.; Novikova, T.A. Synthesis of New Nitroamino-Containing 1,2,4-Triazines by Reaction of 1-Amino-2-nitroguanidine with $\alpha$-Diketones. Russ. J. Org. Chem. 2018, 88, 1381-1384. [CrossRef]

72. Scott, F.L.; Kennedy, M.T.; Reilly, J. Studies in the Pyrazole Series. II. The 1-Nitroguanyl type. J. Am. Chem. Soc. 1953, 75, 1294-1297. [CrossRef]

73. Zhang, Q.H.; He, C.L.; Yin, P.; Shreeve, J.M. Insensitive Nitrogen-Rich Materials Incorporating the Nitroguanidyl Functionality. Chem. Asian J. 2014, 9, 212-217. [CrossRef]

74. Lieber, E.; Sherman, E.; Henry, R.A.; Cohen, J. The Reaction of Nitrous Acid with Nitroaminoguanidine. J. Am. Chem. Soc. 1951, 73, 2327-2329. [CrossRef]

75. O'Connor, T.E.; Fleming, G.; Reilly, J. Diazotization of Nitroaminoguanidine. J. Soc. Chem. Ind. 1949, 68, 309-310. [CrossRef]

76. Xue, H.; Gao, H.X.; Twamley, B.; Shreeve, J.M. Energetic Salts of 3-Nitro-1,2,4- triazole-5-one, 5-Nitroaminotetrazole, and Other Nitro-Substituted Azoles. Chem. Mater. 2007, 19, 1731-1739. [CrossRef]

77. Astakhov, A.M.; Vasiliev, A.D.; Molokeev, M.S.; Sirotinin, A.M.; Kruglyakova, L.A.; Stepanov, R.S. Crystal and Molecular Structure of Nitramino Derivatives of Tetrazole and 1,2,4- Triazole. II. 5-Nitraminotetrazole Diammonium Salt. J. Struct. Chem. 2004, 45, 175-180. [CrossRef]

78. Vasiliev, A.D.; Astakhov, A.M.; Nefedov, A.A.; Stepano, R.S. Crystal and Molecular Structure of Monoammonium Salt of 5-nitroaminotetrazole. J. Struct. Chem. 2003, 44, 322-325. [CrossRef]

79. Astakhov, A.M.; Vasiliev, A.D.; Molokeev, M.S.; Sirotinin, A.M.; Stepanov, R.S. Crystal and Molecular Structure of Nitraminotetrazoles and Nitramino-1,2,4-triazoles. V. 5-Nitraminotetrazole methylammonium salt. J. Struct. Chem. 2005, 46, 517-522. [CrossRef]

80. Vasiliev, A.D.; Astakhov, A.M.; Molokeev, M.S.; Kruglyakova, L.A.; Sirotinin, A.M.; Stepanov, R.S. Crystal and Molecular Structure of the Nitramino Derivatives of Tetrazole and 1,2,4-Triazole. III. 5-Nitraminotetrazole Lithium Salt Monohydrate. J. Struct. Chem. 2004, 45, 360-364. [CrossRef]

81. Astakhov, A.M.; Vasiliev, A.D.; Molokeev, M.S.; Kruglyakova, L.A.; Sirotinin, A.M.; Stepanov, R.S. Crystal and Molecular Structure of Nitraminotetrazole and Nitramino-1,2,4- triazole. IV. 5-Nitraminotetrazole Sodium Salt Sesquihydrate. J. Struct. Chem. 2004, 45, 537-540. [CrossRef]

82. Tappan, B.C.; Incarvito, C.D.; Rheingold, A.L.; Brill, T.B. Thermal Decomposition of Energetic Materials 79 Thermal, Vibrational, and X-ray Structural Characterization of Metal Salts of Mono- and Di-anionic 5-Nitraminotetrazole. Thermochim. Acta 2002, 384, 113-120. [CrossRef]

83. Palopoli, S.F.; Geib, S.J.; Rheingold, A.L.; Brill, T.B. Synthesis and Modes of Coordination of Energetic Nitramine Ligands in Copper (II), Nickel (II), and Palladium (II) Complexes. Inorg. Chem. 1988, 27, $2963-2971$. [CrossRef]

84. Semenov, S.N.; Rogachev, A.Y.; Eliseeva, S.V.; Belousov, Y.A.; Drozdov, A.A.; Troyanov, S.I. 5-Nitroaminotetrazole as a Building Block for Extended Network Structures: Syntheses and Crystal Structures of a Number of Heavy Metal Derivatives. Polyhedron 2007, 26, 4899-4907. [CrossRef]

85. Ozerova, O.Y.; Efimova, T.P.; Novikova, T.A.; Gurzhii, V.V.; Berestovitskaya, V.M. Structure and Synthesis of 3,5-Dimethyl-N-nitro-1H-pyrazole-1-carboxamidine. Russ. J. Gen. Chem. 2015, 85, 1623-1628. [CrossRef]

86. Metelkina, E.L.; Novikova, T.A. Substituted 2-Nitroguanidines in Reactions with Hydrazine Hydrate. Zh. Org. Khim. 1993, 12, 2386-2389. 
87. Aboudi, J.; Bayat, Y.; Abedi, Y.; Nabati, M.; Mahkam, M. 3-Nitro, 1-Amino Guanidine and 5-Hydrazino-1HTetrazole Derivatives as New Energetic Materials. Iran. J. Chem. Chem. Eng. 2015, 34, 1-16.

88. Gao, H.X.; Shreeve, J.M. The Many Faces of FOX-7: A Precursor to High-Performance Energetic Materials. Angew. Chem. Int. Ed. 2015, 54, 6335-6338. [CrossRef] [PubMed]

89. Impact: Insensitive $>40 \mathrm{~J}$, less sensitive $>35 \mathrm{~J}$, sensitive $>4 \mathrm{~J}$, very sensitive $<3 \mathrm{~J}$. Friction: Insensitive $>360 \mathrm{~N}$, less sensitive $=360 \mathrm{~N}$, sensitive $>80 \mathrm{~N}$, very sensitive $>10 \mathrm{~N}$, extremely sensitive $<10 \mathrm{~N}$. According to the $U N$ Recommendations on the Transport. of Dangerous Goods.

Sample Availability: Samples of the compounds are not available from the authors.

(C) 2019 by the authors. Licensee MDPI, Basel, Switzerland. This article is an open access article distributed under the terms and conditions of the Creative Commons Attribution (CC BY) license (http://creativecommons.org/licenses/by/4.0/). 